\title{
Dual benefit of ocean acidification for the laminarialean kelp Saccharina latissima: enhanced growth and reduced herbivory
}

\author{
Craig S. Young, Michael H. Doall, Christopher J. Gobler* \\ School of Marine and Atmospheric Sciences, Stony Brook University, Southampton, NY 11968, USA
}

\begin{abstract}
The laminarialean kelp Saccharina latissima is a common macroalga along rocky shorelines that is also frequently used in aquaculture. This study examined how ocean acidification may alter the growth of $S$. latissima as well as grazing on $S$. latissima by the gastropod Lacuna vincta. Under elevated nutrients, $S$. latissima experienced significantly enhanced growth at $p \mathrm{CO}_{2}$ levels $\geq 1200 \mu \mathrm{atm}$ compared to ambient $p \mathrm{CO}_{2}(\sim 400 \mu \mathrm{atm})$. Elevated $p \mathrm{CO}_{2}(\geq 830 \mu \mathrm{atm})$ also significantly reduced herbivory of $L$. vincta grazing on $S$. latissima relative to ambient $p \mathrm{CO}_{2}$. There was no difference in grazing of $S$. latissima previously grown under elevated or ambient $p \mathrm{CO}_{2}$, suggesting lowered herbivory was due to harm to the gastropods rather than alteration of the biochemical composition of the kelp. Decreased herbivory was specifically elicited when $L$. vincta were exposed to elevated $p \mathrm{CO}_{2}$ in the absence of food for $\geq 18 \mathrm{~h}$ prior to grazing, with reduced grazing persisting $72 \mathrm{~h}$. Elevated growth of $S$. latissima and reduced grazing by L. vincta at $1200 \mu \mathrm{atm} p \mathrm{CO}_{2}$ combined to increase net growth rates of $S$. latissima more than 4 -fold relative to ambient $p \mathrm{CO}_{2}$. L. vincta consumed $70 \%$ of daily production by $S$. latissima under ambient $p \mathrm{CO}_{2}$ but only 38 and $9 \%$ at 800 and $1200 \mu a t m$, respectively. Collectively, decreased grazing by L. vincta coupled with enhanced growth of $S$. latissima under elevated $p \mathrm{CO}_{2}$ demonstrates that increased $\mathrm{CO}_{2}$ associated with climate change and/or coastal processes will dually benefit commercially and ecologically important kelps by both promoting growth and reducing grazing pressure.
\end{abstract}

KEY WORDS: Ocean acidification $\cdot$ Kelp $\cdot$ Gastropods $\cdot$ Grazing

\section{INTRODUCTION}

Ocean acidification is changing marine ecosystems. As anthropogenic $\mathrm{CO}_{2}$ accumulates in the atmosphere and surface oceans, levels of $\mathrm{pH}_{1} \mathrm{CO}_{3}{ }^{2-}$, and the saturation states of calcium carbonate are declining (Doney et al. 2009, Feely et al. 2009). In addition, many coastal ecosystems can experience partial pressure of $\mathrm{CO}_{2}\left(p \mathrm{CO}_{2}\right)$ levels not projected to occur in open ocean systems until the year 2100 (>1000 $\mu \mathrm{atm}$ ) due to a multitude of processes, including upwelling (Feely et al. 2008), riverine discharge (Vargas et al. 2016), macrophyte respiration (Wahl et al. 2018), and eutrophication-enhanced microbial

${ }^{*}$ Corresponding author: christopher.gobler@stonybrook.edu respiration (Wallace et al. 2014). These changes in ocean chemistry stand to reorganize the function of coastal ecosystems, as acidification can be inhibitory to some marine animals (Poloczanska et al. 2016), especially calcifiers (Talmage \& Gobler 2010, Young et al. 2019), but may benefit other ocean organisms (Koch et al. 2013, Young \& Gobler 2016).

Saccharina latissima (also known as sugar kelp) is a bladed, cold-water brown macroalga that is widely distributed across the North Atlantic, Pacific, and Arctic Oceans (Brinkhuis et al. 1983, Sivertsen \& Bjørge 2015). S. latissima can form dense, highly productive and biologically diverse beds that provide numerous ecosystem services, including nursery

() The authors 2021. Open Access under Creative Commons by Attribution Licence. Use, distribution and reproduction are unrestricted. Authors and original publication must be credited. 
habitat, refuge from predators, coastal defense, carbon and nitrogen sequestration, and food sources for other organisms (Norderhaug et al. 2005, Chung et al. 2013, Smale et al. 2013). More recently, the commercial importance and aquaculture of $S$. latissima and other species of kelp has grown (Marinho et al. 2015). Excessive grazing, however, can significantly lower kelp abundance and ecosystem function (Scheibling et al. 1999, Norderhaug \& Christie 2009). Moreover, global distributions of $S$. latissima are declining due to increasing temperatures (Filbee-Dexter et al. 2016), eutrophication (Moy \& Christie 2012), and overfishing of the predators of kelp grazers (Steneck et al. 2002). However, recent evidence suggests that elevated $p \mathrm{CO}_{2}$ associated with ocean acidification could benefit some species of kelp, potentially counteracting the processes contributing to their decline (Hepburn et al. 2011).

Beyond climate change, eutrophication may also act to negatively impact kelp communities. In some temperate regions, excessive nutrient loading can initiate a succession whereby kelp forests become overgrown by turf algae (Eriksson et al. 2002, Connell et al. 2008) and this succession may be accelerated by acidification (Connell \& Russell 2010). Still, kelp can also exist in ecosystems where turf algae are rare, and kelp can be purposely grown in more eutrophic locales for aquaculture purposes (Kim et al. 2015, Jiang et al. 2020). While climate change and eutrophication are strong environmental drivers in coastal ecosystems, the manner in which nutrients and acidification act, and potentially interact, to directly alter kelp growth is not fully clear.

The northern Lacuna snail Lacuna vincta (Gastropoda) is a common grazer in coastal North Atlantic and North Pacific ecosystems (Chavanich \& Harris 2002, Janiak \& Whitlatch 2012) and is a well-known grazer of macroscopic kelp sporophytes (BradyCampbell et al. 1984, Johnson \& Mann 1986). Grazing by large populations of $L$. vincta can cause extensive damage to kelp blades in kelp beds (Chenelot \& Konar 2007, Krumhansl \& Scheibling 2011), consuming up to $10 \%$ of the surface area of S. latissima (Molis et al. 2010, Krumhansl \& Scheibling 2011). The resulting damage done by the grazer on the kelp blade, meristem, and stipe can significantly lower the tensile strength of the kelp, making it more susceptible to breakage (Chenelot \& Konar 2007, Molis et al. 2010). High grazing intensity by L. vincta on the reproductive sorus tissue of $S$. latissima may exacerbate recruitment limitation and further hinder the recovery of degraded kelp beds (O'Brien \& Scheibling 2016). Compared to other macroalgae native to the northern Atlantic Ocean, laminarialean kelps are preferred by L. vincta due to overall lower phlorotanins (anti-grazing defense) and relatively high palatability (Wakefield \& Murray 1998). While ocean acidification can disrupt the grazing by L. vincta on some macroalgae (Young et al. 2019), the manner in which $L$. vincta herbivory on kelps might be altered by this process is unknown.

The overarching objective of this study was to assess how coastal acidification may affect Northwest Atlantic populations of $S$. latissima. Experiments quantified the growth rates as well as elemental and isotopic content of $S$. latissima under treatment levels of $p \mathrm{CO}_{2}$ with and without nutrients. Experiments were also performed to quantify herbivory rates of $L$. vincta on $S$. latissima under normal and elevated levels of $p \mathrm{CO}_{2}$. Given that prior research has determined that the effects of acidification on grazing by $L$. vincta are dose-dependent with regard to both $p \mathrm{CO}_{2}$ levels and exposure duration (Young et al. 2019), experiments exploring differing levels of $p \mathrm{CO}_{2}$ and differing durations of exposure were performed. Given that the effects of acidification on invertebrates can depend on food supply (Melzner et al. 2011, Thomsen et al. 2013, Pansch et al. 2014), exposures to acidification were made following periods of ad libitum and restricted feeding. Finally, the net growth rates (growth minus grazing) of $S$. latissima were determined under treatment $p \mathrm{CO}_{2}$ conditions, providing a novel examination of the net effects of ocean acidification on a keystone macrophyte. While studies exploring how ocean acidification affects herbivory have been limited, to our knowledge this is the first study to assess how ocean acidification concurrently alters growth and grazing for a macrophyte.

\section{MATERIALS AND METHODS}

\subsection{Collection and preparation of Lacuna vincta and Saccharina latissima}

Lacuna vincta used for this study were collected by hand during low tide from Shinnecock Bay, NY, USA $\left(40.85^{\circ} \mathrm{N}, 72.50^{\circ} \mathrm{W}\right)$, part of New York's South Shore Estuary Reserve (NYSSER) (Fig. S1 in the Supplement at www.int-res.com/articles/suppl/m664p087_supp. pdf). L. vincta are an abundant macroalgae grazer in estuaries of the northeastern USA (Chavanich \& Harris 2002, Janiak \& Whitlatch 2012) and were identified based on morphology. Saccharina latissima used in the study was cultured from blades collected from 
Long Island Sound, spawned on line, and grown along horizontal longlines at a commercial oyster farm (i.e. Great Gun Shellfish) in Moriches Bay, NY $\left(40.78^{\circ} \mathrm{N}, 72.78^{\circ} \mathrm{W}\right)$, a lagoon contiguous with Shinnecock Bay to the east. Large, well-pigmented blades of $S$. latissima were selected from samples collected by hand at low tide (Fig. S1). S. latissima were cut from their holdfasts as close to the longlines as possible. Following collection, S. latissima and L. vincta were immediately placed in seawater-filled containers and transported to the Stony Brook Southampton Marine Science Center of Stony Brook University within $30 \mathrm{~min}$ of collection. Upon arrival to the facility, L. vincta were placed in a 201 polycarbonate vessel filled with filtered $(0.2 \mu \mathrm{m})$ seawater taken from the collection site. The vessel was supplied with air and recently collected $S$. latissima as a food source until experiments were initiated (Duffy et al. 2014). S. latissima used in experiments were placed in a large, round $2000 \mathrm{l}$ tank filled with flowing, $1 \mu \mathrm{m}$ filtered seawater from Shinnecock Bay.

For experiments performed to quantify algal growth rates in response to elevated $p \mathrm{CO}_{2}$ and/or nutrients, individual $S$. latissima rectangular sporophytes were prepared by cutting the stipe $2.5 \mathrm{~cm}$ below the blade-stipe interface and cutting the blade $5 \mathrm{~cm}$ above the blade-stipe interface. This was done to standardize initial kelp blade tissue type and size (Boderskov et al. 2016). S. latissima samples were weighed on a Scientech ZSA 120 digital microbalance $( \pm 0.0001 \mathrm{~g})$ to obtain initial fresh weight in grams. For experiments performed to quantify grazing rates on $S$. latissima, rectangular sections $(2 \times$ $4 \mathrm{~cm}$, length $\times$ width) of the algae were cut from large blades with care taken to ensure uniformity of size, shape, and tissue type. Sections from the upper blades of $S$. latissima were used due to L. vincta's preference for this section of the organism over the lower blade, meristem, or stipe (Molis et al. 2010). All samples were spun in a salad spinner to remove debris and epiphytes, extensively rinsed with filtered $(0.2 \mu \mathrm{m})$ seawater before being spun again to further remove any remaining debris, epiphytes, and excess seawater (Young \& Gobler 2016), and weighed as described above.

\subsection{Preparation of experiments}

Two experiments were performed to assess the effects of $p \mathrm{CO}_{2}$ and nutrients on the growth rates of $S$. latissima and 5 experiments were performed to assess the effects of elevated $p \mathrm{CO}_{2}$ on the herbivory rates of $L$. vincta on $S$. latissima. Each experiment was performed in 11 polycarbonate vessels that were acid-washed $(10 \% \mathrm{HCl})$ and liberally rinsed with deionized water. All experimental containers were placed in an environmental control chamber set to a temperature $\left(\sim 10-18^{\circ} \mathrm{C}\right)$, light intensity $(\sim 250 \mu \mathrm{mol}$ photons $\left.\mathrm{m}^{-2} \mathrm{~s}^{-1}\right)$, and duration (12 h light:12 h dark cycle) that matched ambient conditions at the collection site to allow for optimal conditions for L. vincta and S. latissima. As temperatures rose through the spring, so did the temperatures used for experiments to minimize thermal shock to the kelp and snails. All containers were filled with filtered seawater, randomly placed within the environmental control chamber, and randomly assigned in quadruplicate to each treatment, which varied based on the experiment performed. For grazing experiments (see below), 2 additional containers were filled with filtered seawater and assigned, without L. vincta, to assess $S$. latissima residual growth (i.e. additional growth the $S$. latissima samples experienced during the grazing period). During those experiments, the lights of the environmental control chamber were turned off $24 \mathrm{~h}$ prior to the introduction of Lacuna in order to minimize residual $S$. latissima growth (Nelson et al. 2008, Young et al. 2019). For each grazing experiments, $8 \mathrm{~L}$. vincta $(\sim 3 \mathrm{~mm})$ were added to each separate container, mimicking densities found on macroalgae at the collection site (0.5-1 grazer $\left.\mathrm{cm}^{-2}\right)$ and reported in the literature (Chenelot \& Konar 2007, Dubois \& Iken 2012, Young et al. 2019).

Dissolved gases were delivered into each experimental container via air diffusers (Pentair) connected to $1 \mathrm{ml}$ polystyrene serological pipettes inserted into the bottom of each vessel and connected via Tygon tubing to an air source. The containers that were subjected to treatment $\mathrm{CO}_{2}$ conditions utilized multitube gas proportioner systems (Cole Parmer ${ }^{\circledR}$ Flowmeter) to mix ambient air with $5 \% \mathrm{CO}_{2}$ (Talmage \& Gobler 2010). The containers subjected to ambient conditions utilized single tube proportioner systems to introduce only ambient air into the containers. The gases were mixed through gang valves and were delivered at a flow rate of $2500 \pm 5 \mathrm{ml} \mathrm{min} \mathrm{m}^{-1}$ to experimental containers through serological pipettes inserted through plexiglass covers on the containers. The bubbling rates in the containers turned over the volume $>1000$ times $\mathrm{d}^{-1}$, and bubbling was initiated at least 2-3 d prior to the initiation of experiments to allow $\mathrm{CO}_{2}$ levels and carbonate chemistry to reach a state of equilibrium. A Honeywell DuraFET III ion-sensitive field effect transistor-based (ISFET) solid-state $\mathrm{pH}$ sensor $( \pm 0.01 \mathrm{pH}$ unit, total scale) was used to measure $\mathrm{pH}$ 
within containers each day of the experiments. Dissolved inorganic carbon (DIC) within experimental vessels was measured directly from water samples that were collected at the beginning and end of experiments and preserved using a saturated mercuric chloride $\left(\mathrm{HgCl}_{2}\right)$ solution and stored at $\sim 4^{\circ} \mathrm{C}$ until they were analyzed on a VINDTA 3D (Versatile Instrument for the Determination of Total inorganic carbon) delivery system coupled within a UIC Inc. coulometer (model CM5017O). During the coulometric analyses, all inorganic carbon species were converted to $\mathrm{CO}_{2}$ gas by the addition of excess hydrogen to the sample, and the evolved $\mathrm{CO}_{2}$ gas was subsequently carried into the titration cell of the coulometer. The gas then reacted quantitatively with an ethanolamine-based reagent to generate hydrogen ions, which are titrated with coulometrically generated $\mathrm{OH}^{-}$, and $\mathrm{CO}_{2}$ was measured by integrating the total change required to titrate the hydrogen ions (Johnson et al. 1993). The $p \mathrm{CO}_{2}$ concentrations (Table 1) were calculated from measured levels of DIC, $\mathrm{pH}$, temperature, salinity, and the first and second dissociation constants of carbon acid in seawater (Millero 2010) using the program CO2SYS (http://cdiac.ess-dive. lbl.gov/ftp/co2sys/). Certified reference material (CRM) provided by Dr. Andrew Dickson (University of California, San Diego, Scripps Institution of Oceanography; Batch $180=2021.87 \mu \mathrm{mol}$ DIC $\mathrm{kg}^{-1}$ seawater) was used as a quality assurance measure, and analyses only proceeded when recovery of the CRM was 99.8-100\%. Final DIC concentration of the CRM was $2019.85 \mu \mathrm{mol}$ DIC $\mathrm{kg}^{-1}$ seawater.

\subsection{Assessing the effects of elevated nutrients and $\mathrm{pCO}_{2}$ on $\mathrm{S}$. latissima}

To quantify the effects of elevated $p \mathrm{CO}_{2}$ and/or nutrients on the growth of S. latissima, 2 experiments were performed. In the first experiment (designated as 'Co-effects of $p \mathrm{CO}_{2}$ and nutrients'; Table 2), the goal was to assess how high and low $p \mathrm{CO}_{2}$ and nutrients altered the growth rates of $S$. latissima. Estuaries are dynamic environments where levels of nutrients and $p \mathrm{CO}_{2}$ vary in time and space (Wallace et al. 2014, R. B. Wallace et al. unpubl. data). Given prior studies (Olischläger et al. 2012, Zhang et al. 2020), we hypothesized that elevated $p \mathrm{CO}_{2}$ would increase $S$. latissima growth, but that ele-

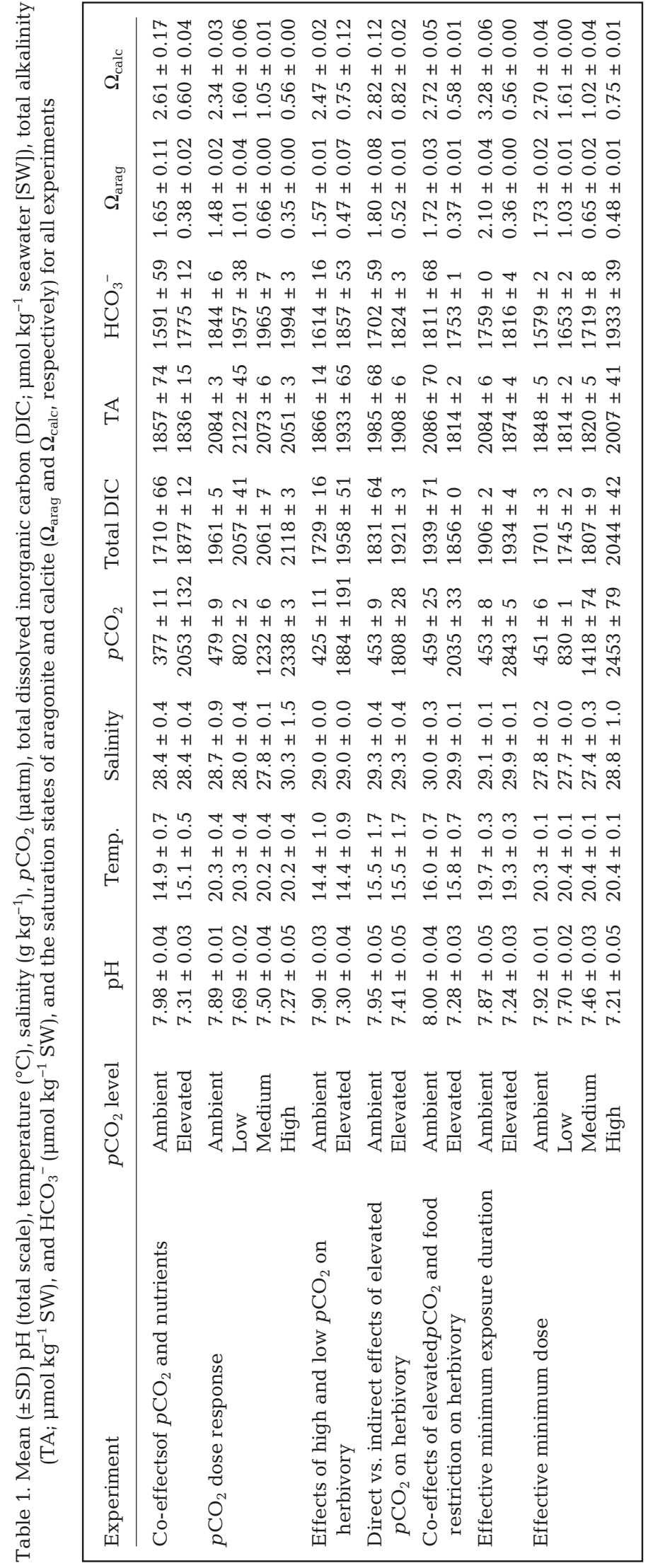


Table 2. List of experiments with their respective incubation or starvation and grazing periods, and conditions

\begin{tabular}{|c|c|c|c|c|}
\hline Experiment & \multicolumn{2}{|c|}{ Incubation period (d) } & Figure no. & Experimental conditions \\
\hline Co-effects of $p \mathrm{CO}_{2}$ and nutrients & \multicolumn{2}{|c|}{7} & 1 & $\begin{array}{l}\text { Saccharina latissima incubated under ambient } \\
\text { or elevated } p \mathrm{CO}_{2} \text { with and without nutrient } \\
\text { additions }\end{array}$ \\
\hline \multirow[t]{2}{*}{$p \mathrm{CO}_{2}$ dose response } & \multicolumn{2}{|c|}{14} & 2 & S. latissima incubated under treatment $p \mathrm{CO}_{2}$ \\
\hline & $\begin{array}{l}\text { Starvation } \\
\text { period (h) }\end{array}$ & $\begin{array}{l}\text { Grazing } \\
\text { period (h) }\end{array}$ & & \\
\hline $\begin{array}{l}\text { Effects of high and low } p \mathrm{CO}_{2} \\
\text { on herbivory }\end{array}$ & 24 & 48 & 4 & $\begin{array}{l}\text { Lacuna vincta starved and grazed under } \\
\text { ambient or elevated } p \mathrm{CO}_{2} \text { on } S \text {. latissima that } \\
\text { was grown at ambient } p \mathrm{CO}_{2} \text { levels }\end{array}$ \\
\hline $\begin{array}{l}\text { Direct vs. indirect effects of } \\
\text { elevated } p \mathrm{CO}_{2} \text { on herbivory }\end{array}$ & 24 & 96 & 5 & $\begin{array}{l}\text { L. vincta starved under ambient or elevated } \\
p \mathrm{CO}_{2 i} \text { half of snails from each group grazed } \\
\text { under ambient and elevated } p \mathrm{CO}_{2} \text { on } S \text {. latissima } \\
\text { that was pre-incubated for } \sim 1 \mathrm{wk} \text { under ambient } \\
\text { or elevated } p \mathrm{CO}_{2}\end{array}$ \\
\hline $\begin{array}{l}\text { Co-effects of elevated } p \mathrm{CO}_{2} \text { and } \\
\text { food restriction on herbivory }\end{array}$ & 24 & 24 & 6 & $\begin{array}{l}\text { L. vincta starved or fed under ambient or elevated } \\
p \mathrm{CO}_{2} \text { for } 24 \mathrm{~h} \text { and then grazed on } S \text {. latissima that } \\
\text { was grown at ambient } p \mathrm{CO}_{2} \text { levels }\end{array}$ \\
\hline $\begin{array}{l}\text { Effective minimum exposure } \\
\text { duration }\end{array}$ & 24 & 24 & 7 & $\begin{array}{l}\text { L. vincta starved under elevated } p \mathrm{CO}_{2} \text { for } 0,6 \text {, } \\
12,18 \text {, or } 24 \mathrm{~h} \text { before grazing on } S \text {. latissima that } \\
\text { was grown at ambient } p \mathrm{CO}_{2} \text { levels }\end{array}$ \\
\hline Effective minimum dose & 24 & 24 & 8 & $\begin{array}{l}\text { L. vincta starved and grazed on } S \text {. latissima } \\
\text { under a range of } p \mathrm{CO}_{2} \text { levels. S. latissima was } \\
\text { grown at ambient } p \mathrm{CO}_{2} \text { levels prior to the } \\
\text { experiment }\end{array}$ \\
\hline
\end{tabular}

vated nutrients might be inhibitory (Connell et al. 2008). S. latissima was placed in 1 of 4 treatments established in quadruplicate (for this and all experiments): a control with ambient $p \mathrm{CO}_{2}$ levels (350450 1atm) and no nutrient additions, a treatment with ambient $p \mathrm{CO}_{2}$ and nutrient additions $(50 \mu \mathrm{M}$ nitrate, $3 \mu \mathrm{M}$ phosphate), a treatment with elevated $p \mathrm{CO}_{2}$ levels ( 1800-2100 $\left.\mu \mathrm{atm}\right)$ and no nutrient additions, and a treatment with elevated $p \mathrm{CO}_{2}$ and nutrient additions. For this experiment, S. latissima samples were incubated under these conditions for $7 \mathrm{~d}$. The elevated nutrients and $p \mathrm{CO}_{2}$ concentrations were higher than levels present at the collection site (0-10 $\mu \mathrm{M}$ nitrate, $0-1 \mu \mathrm{M}$ phosphate, 400-800 $\mu \mathrm{M}$ $p \mathrm{CO}_{2}$ ), but consistent with concentrations present in some US East Coast estuaries, including those in the nearby New York region during winter and spring (Gobler et al. 2006, Wallace et al. 2014). For example, total dissolved nitrogen concentrations exceeding $50 \mu \mathrm{M}$ have been reported in Quantuck Bay (Gobler et al. 2011), the estuary contiguous with and $10 \mathrm{~km}$ from the $S$. latissima collection site, and $p \mathrm{CO}_{2}$ levels in the range of 1000-3000 $\mu$ atm have recently been reported for Shinnecock Bay and the Peconic Estuary (Wallace et al. unpubl. data), systems contiguous with the S. latissima collection site. Given the ability of future ocean acidification to synergistically depress $\mathrm{pH}$ values when coupled with eutrophicationdriven acidification (Sunda \& Cai 2012), we expect future climate change scenarios to increase regional $p \mathrm{CO}_{2}$ concentrations to levels higher than presently observed.

For the second experiment (' $p \mathrm{CO}_{2}$ dose response'; Table 2), the goal was to identify the minimum level of $p \mathrm{CO}_{2}$ needed to yield enhanced growth rates considering the levels currently present in regional estuaries (Wallace et al. 2014, Wallace et al. unpubl. data) and levels that may be present in the coming centuries due to climate change (IPCC 2014). We hypothesized that, like other carbon-limited autotrophs (Raven et al. 2020), growth rates would increase linearly with increasing levels of $p \mathrm{CO}_{2}$. S. latissima samples were placed in 1 of 4 treatments: a control with ambient $p \mathrm{CO}_{2}$ (350-450 $\left.\mu \mathrm{atm}\right)$, a treatment with 750-850 $\mu \mathrm{atm}$ $p \mathrm{CO}_{2}$, a treatment with 1200-1500 uatm $p \mathrm{CO}_{2}$, and a treatment with 1800-2100 $\mu$ atm $p \mathrm{CO}_{2}$. While the higher $p \mathrm{CO}_{2}$ levels used in this and the prior experiment exceed $21^{\text {st }}$ century climate change projections, they capture the range of levels observed in coastal ecosystems influenced by eutrophication (Wallace et 
al. 2014), upwelling (Feely et al. 2008), macrophyte respiration (Wahl et al. 2018), or riverine discharge (Vargas et al. 2016). Each treatment was supplied with nutrients (50 $\mu \mathrm{M}$ nitrate, $3 \mu \mathrm{M}$ phosphate), and $S$. latissima samples were incubated for $\sim 2 \mathrm{wk}$. At the end of the incubation periods for this and the first experiment, samples were removed from their respective treatments, weighed as described above, and final length and width measurements were made. Weight-based growth rates were determined by the following formula:

$$
\mathrm{mg} \mathrm{d}^{-1}=\frac{\left(W_{\text {final }}+W_{\text {initial }}\right) \times 1000}{\Delta t}
$$

where $W_{\text {final }}$ and $W_{\text {initial }}$ are the final and initial fresh weights, in grams, and $\Delta t$ is the duration of the experiment in days.

\subsection{Herbivory by $L$. vincta on $S$. latissima}

Five herbivory experiments were performed, the first of which (designated as 'Effects of high and low $p \mathrm{CO}_{2}$ on herbivory') gauged the herbivory rates of $L$. vincta feeding on S. latissima under ambient (350$400 \mu \mathrm{atm})$ and elevated (1800-2100 $\mu \mathrm{atm}) p \mathrm{CO}_{2}$ levels (Table 2). We hypothesized that $L$. vincta herbivory rates would be lower under higher $p \mathrm{CO}_{2}$ levels (Young et al. 2019). L. vincta were placed in ambient or elevated $p \mathrm{CO}_{2}$ conditions without S. latissima and starved for $24 \mathrm{~h}$ and then placed into containers with $S$. latissima (never exposed to elevated $p \mathrm{CO}_{2}$ ) under ambient or elevated $p \mathrm{CO}_{2}$ for $48 \mathrm{~h}$. At the end of the grazing period, $L$. vincta and $S$. latissima were removed from the containers and $S$. latissima samples were weighed as described above. Herbivory rates were calculated by obtaining the difference in the initial and final corrected weights divided by the number of grazers and the elapsed time of the grazing period and multiplied by 1000 to convert weights to $\mathrm{mg}\left(\mathrm{mg}\right.$ grazer $\left.{ }^{-1} \mathrm{~d}^{-1}\right)$. Final weights were corrected using residual growth of the additional $S$. latissima samples grown without $L$. vincta (see above).

The next experiment ('Direct vs indirect effects of elevated $p \mathrm{CO}_{2}$ on herbivory'; Table 2) was performed to determine if lowered herbivory rates of $L$. vincta under high $p \mathrm{CO}_{2}$ were caused by direct effects on $L$. vincta or indirectly by altering the palatability of $S$. latissima. Given prior studies of this snail, we hypothesized that $L$. vincta herbivory rates would be lowered due to direct exposure to high $p \mathrm{CO}_{2}$ levels and not due to exposure of $S$. latissima to high $p \mathrm{CO}_{2}$ (Young et al. 2019). L. vincta were starved under am-

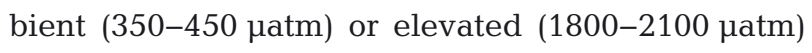
$p \mathrm{CO}_{2}$ levels and feed $S$. latissima incubated under either ambient or elevated $p \mathrm{CO}_{2}$, with the intent of placing one-half of the L. vincta from each $p \mathrm{CO}_{2}$ group in either the $p \mathrm{CO}_{2}$ level they were starved in or the opposite $p \mathrm{CO}_{2}$ group. For this experiment, $S$. latissima was incubated for $\sim 1 \mathrm{wk}$ under ambient or elevated $p \mathrm{CO}_{2}$; on the final day of the incubation period, $L$. vincta were starved in separate vessels under ambient or elevated $p \mathrm{CO}_{2}$ without $S$. latissima for $24 \mathrm{~h}$. At the end of the $1 \mathrm{wk} S$. latissima incubation period and concurrent $24 \mathrm{~h}$ L. vincta starvation period, the lights of the environmental chamber were turned off, and $L$. vincta were introduced into the vessels containing $S$. latissima for a total of 4 treatments: a control with ambient $p \mathrm{CO}_{2}$ containing $L$. vincta starved under ambient $p \mathrm{CO}_{2}$ and allowed to graze on $S$. latissima incubated under ambient $p \mathrm{CO}_{2}$, a treatment with elevated $p \mathrm{CO}_{2}$ containing $L$. vincta starved under ambient $p \mathrm{CO}_{2}$ and allowed to graze on $S$. latissima incubated under elevated $p \mathrm{CO}_{2}$, a treatment with ambient $p \mathrm{CO}_{2}$ containing $L$. vincta starved under elevated $p \mathrm{CO}_{2}$ and allowed to graze on S. latissima incubated under ambient $p \mathrm{CO}_{2}$, and a treatment with elevated $p \mathrm{CO}_{2}$ containing L. vincta starved under elevated $p \mathrm{CO}_{2}$ and allowed to graze on S. latissima incubated under elevated $p \mathrm{CO}_{2}$. Once in their respective containers, $L$. vincta were allowed to graze for $96 \mathrm{~h}$, with $S$. latissima samples being replaced every $24 \mathrm{~h}$ with the same source of $S$. latissima (high or ambient $p \mathrm{CO}_{2}$ exposure). At the end of each $24 \mathrm{~h}$ grazing period, $S$. latissima samples were removed from the containers and were weighed as described above and herbivory was calculated.

Given that the effects of acidification on invertebrates can depend on food supply (Melzner et al. 2011, Thomsen et al. 2013, Pansch et al. 2014), for the next experiment ('Co-effects of elevated $p \mathrm{CO}_{2}$ and food restriction on herbivory'; Table 2), herbivory rates of $L$. vincta were quantified on individuals that were either starved or fed under ambient (350$450 \mu \mathrm{atm})$ or elevated $p \mathrm{CO}_{2}(1800-2100 \mu \mathrm{atm})$ for $24 \mathrm{~h}$. Given prior studies, we hypothesized that $L$. vincta exposure to high $p \mathrm{CO}_{2}$ during the starvation period would yield lowered herbivory rates while exposure during the grazing period would not (Young et al. 2019). There were 4 treatments: starved under ambient $p \mathrm{CO}_{2}$, fed at ambient $p \mathrm{CO}_{2}$, starved under high $p \mathrm{CO}_{2}$, or fed at high $p \mathrm{CO}_{2}$. After $24 \mathrm{~h}$, fresh $S$. latissima blade portions were placed in the containers and $L$. vincta were allowed to graze for $24 \mathrm{~h}$. At the end of the grazing periods, $L$. vincta and $S$. latissima were removed from the containers and 
S. latissima samples were weighed as described above and herbivory was calculated.

The final experiments were performed to determine how the intensity and duration of $\mathrm{CO}_{2}$ exposure altered herbivory of $L$. vincta grazing on $S$. latissima. These experiments specifically assessed the effective minimum duration of elevated $p \mathrm{CO}_{2}$ required to alter herbivory rates ('Effective minimum exposure duration'; Table 2) and the effective minimum concentration of $p \mathrm{CO}_{2}$ to alter herbivory rates of $L$. vincta ('Effective minimum dose'; Table 2). Given that $p \mathrm{CO}_{2}$ concentrations can vary diurnally within shallow estuaries (Baumann et al. 2015) and that even short-term exposure to acidification can disrupt herbivory (Young et al. 2019), the 'effective minimum exposure duration' experiment was designed to identify the minimum duration exposure needed to disrupt herbivory in $L$. vincta. We hypothesized that exposure to high $p \mathrm{CO}_{2}$ for less than $24 \mathrm{~h}$ would still lower grazing rates (Young et al. 2019). There were 5 treatments in this experiment: a control with ambient $p \mathrm{CO}_{2}(350-450 \mu \mathrm{atm})$ during the $24 \mathrm{~h}$ starvation period (no dose), a treatment with elevated $\mathrm{pCO}_{2}$ (1800-2100 $\mu \mathrm{atm})$ during the entire $24 \mathrm{~h}$ starvation period, and treatments with 6,12 , and $18 \mathrm{~h}$ of exposure to elevated $p \mathrm{CO}_{2}$ during the starvation period with 18,12 , and $6 \mathrm{~h}$, respectively, of ambient $p \mathrm{CO}_{2}$ exposure prior to exposure to elevated $p \mathrm{CO}_{2}$. At the end of the starvation period, $L$. vincta were placed in containers with ambient $p \mathrm{CO}_{2}$ levels, S. latissima samples were introduced, and $L$. vincta were allowed to graze for $24 \mathrm{~h}$, after which herbivory rates were calculated. Given that $p \mathrm{CO}_{2}$ levels can be dynamic in estuaries (Wallace et al. 2014) and that levels of $p \mathrm{CO}_{2}$ are expected to more than double this century, the 'effective minimum dose' experiment was conducted to assess how levels of $p \mathrm{CO}_{2}$ found in estuaries today (Wallace et al. 2014) as well as those projected for the future in less impacted regions (IPCC 2014 ) affect herbivory by $L$. vincta. Given prior studies with $L$. vincta, we hypothesized that moderately elevated ( $>1500 \mu \mathrm{atm})$ concentrations of $p \mathrm{CO}_{2}$ would significantly lower herbivory rates (Young et al. 2019). This experiment established 4 treatments: a control with ambient $p \mathrm{CO}_{2}(350-450 \mu \mathrm{atm})$, a treatment with slightly elevated $p \mathrm{CO}_{2}$ (750-850 $\left.\mu \mathrm{atm}\right)$, a treatment with moderately elevated $p \mathrm{CO}_{2}(1200-$ $1500 \mu \mathrm{atm})$, and a treatment with high $p \mathrm{CO}_{2}(1800-$ $2100 \mu \mathrm{atm})$. During this experiment, $L$. vincta were placed in 1 of the 4 treatments and starved for $24 \mathrm{~h}$. At the end of the starvation period, S. latissima samples were introduced, and $L$. vincta were allowed to graze for $24 \mathrm{~h}$ at their respective $p \mathrm{CO}_{2}$ levels. At the end of the grazing period, L. vincta and S. latissima were removed from the containers and $S$. latissima samples were weighed as described above and herbivory was calculated.

\subsection{Post-experimental analyses}

For carbon (C) and nitrogen (N) analyses of S. latissima, frozen samples were dried at $60^{\circ} \mathrm{C}$ for $24 \mathrm{~h}$, and then homogenized into a fine powder with a mortar and pestle. Tissue $\mathrm{C}, \mathrm{N}$, and $\delta^{13} \mathrm{C}$ were analyzed using an elemental analyzer interfaced to a Europa 20-20 isotope ratio mass spectrometer at the UC Davis Stable Isotope Facility. The measured $\delta^{13} \mathrm{C}$ levels of the $\mathrm{CO}_{2}$ gas $(-80 \%)$ used in experiments and isotopic mixing models (Young \& Gobler 2016, 2017) were used to identify the relative use of $\mathrm{CO}_{2}$ and $\mathrm{HCO}_{3}{ }^{-}$by $S$. latissima.

Net algal growth rates were calculated using growth rates and total herbivory rates from the ' $p \mathrm{CO}_{2}$ dose response' and 'effective minimum dose' experiments, respectively. The herbivory rates for each replicate in each $p \mathrm{CO}_{2}$ treatment in the 'effective minimum dose' experiment were calculated by subtracting the final $S$. latissima fresh weight from the initial fresh weight. We note that the S. latissima in this herbivory experiment were all raised at ambient $p \mathrm{CO}_{2}$. The mean total herbivory rate for each $p \mathrm{CO}_{2}$ treatment was subtracted from the $S$. latissima growth rates in the corresponding $p \mathrm{CO}_{2}$ treatment in the ' $p \mathrm{CO}_{2}$ dose response' experiment to obtain the net growth rate (growth minus herbivory) for $4 \mathrm{pCO}_{2}$ levels.

One-way ANOVAs were performed within SigmaPlot 11.0 to assess significant differences in herbivory rates in the ' $p \mathrm{CO}_{2}$ dose response', 'effects of high and low $p \mathrm{CO}_{2}$ on herbivory', 'effective minimum exposure duration', and 'effective minimum dose' experiments ( $\mathrm{n}=4$ treatment $^{-1}$ for each experiment). Two-way ANOVAs were performed with SigmaPlot to assess herbivory rates in the 'co-effects of $p \mathrm{CO}_{2}$ and nutrients', 'direct vs. indirect effects of elevated $p \mathrm{CO}_{2}$ on herbivory', and 'co-effects of elevated $p \mathrm{CO}_{2}$ and food restriction on herbivory' experiments ( $\mathrm{n}=4$ treatment $^{-1}$ for each experiment), where the main treatment effects were $p \mathrm{CO}_{2}$ and nutrient levels (ambient or elevated for both) for the 'co-effects of $p \mathrm{CO}_{2}$ and nutrients' experiment, $p \mathrm{CO}_{2}$ level for the $S$. latissima incubation and $L$. vincta starvation periods (ambient and elevated for both) for the 'direct vs. indirect effects of elevated $p \mathrm{CO}_{2}$ on herbivory' experiment, and $p \mathrm{CO}_{2}$ level (ambient or elevated) and starvation (starved or not starved) for the 'co-effects of elevated 
$p \mathrm{CO}_{2}$ and food restriction on herbivory' experiment. Normality and equal variance were tested via the use of Shapiro-Wilk and Leven tests within SigmaPlot 11.0; assumptions of equal variance and normality were met for all data. For all experiments, if significant differences were detected, a Tukey's HSD test using $R$ v.3.4.0 within RStudio v.1.0.143 was performed (R Core Team 2020, RStudio Team 2020).

\section{RESULTS}

\subsection{Effects of elevated $p \mathrm{CO}_{2}$ and nutrients on Saccharina latissima growth rates}

In the 'co-effects of $p \mathrm{CO}_{2}$ and nutrients' experiment, growth rates of Saccharina latissima were significantly higher in elevated than in ambient $p \mathrm{CO}_{2}$ by $70 \%$ (2-way ANOVA and Tukey's HSD, p $<0.05$; Fig. 1, Tables S1 \& S2 in the Supplement). Furthermore, growth rates were significantly higher by $\sim 50 \%$ under elevated nutrient conditions relative to treatments that did not receive nutrient additions (2-way ANOVA and Tukey's HSD, p < 0.05; Fig. 1, Tables S1 \& S2), and there was no interaction between nutrient additions and $p \mathrm{CO}_{2}$ levels (Fig. 1).

For the ' $p \mathrm{CO}_{2}$ dose response' experiment, growth rates in the $\sim 1200$ and $\sim 2300 \mu \mathrm{atm} p \mathrm{CO}_{2}$ treatments were double the ambient ( $500 \mu \mathrm{atm}) p \mathrm{CO}_{2}$ treatment (1-way ANOVA and Tukey's HSD, $\mathrm{p}<0.05$ for both; Fig. 2, Tables S3 \& S4) but were not different from each other. While growth rates were $45 \%$ higher in the $800 \mu \mathrm{atm} p \mathrm{CO}_{2}$ treatment relative to the ambient treatment, the difference was not statistically different

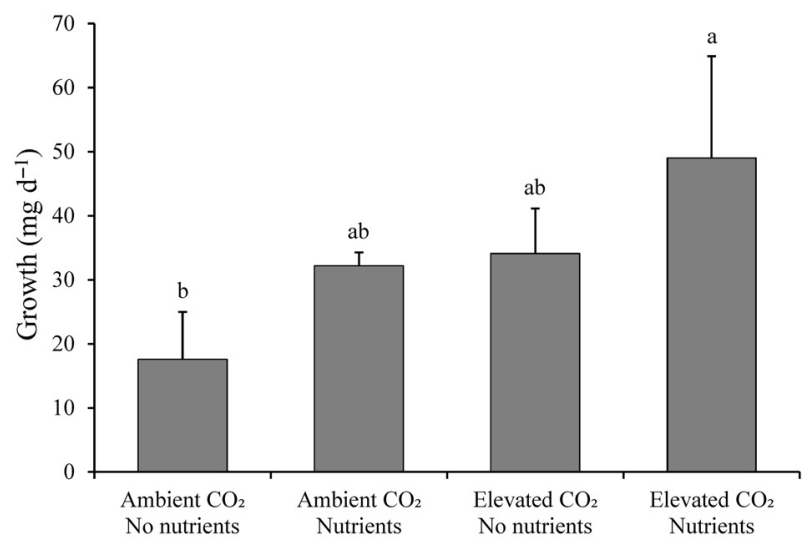

Fig. 1. Mean (SD) growth rates of Saccharina latissima under ambient and elevated $p \mathrm{CO}_{2}$ levels with nutrient additions ('Co-effects of $p \mathrm{CO}_{2}$ and nutrients'; Table 2). Statistical analyses: 2-way ANOVA and post hoc Tukey's HSD tests $(\mathrm{n}=4$ for all treatments); significant differences $(\mathrm{p}<0.05)$ between treatments are indicated by letters

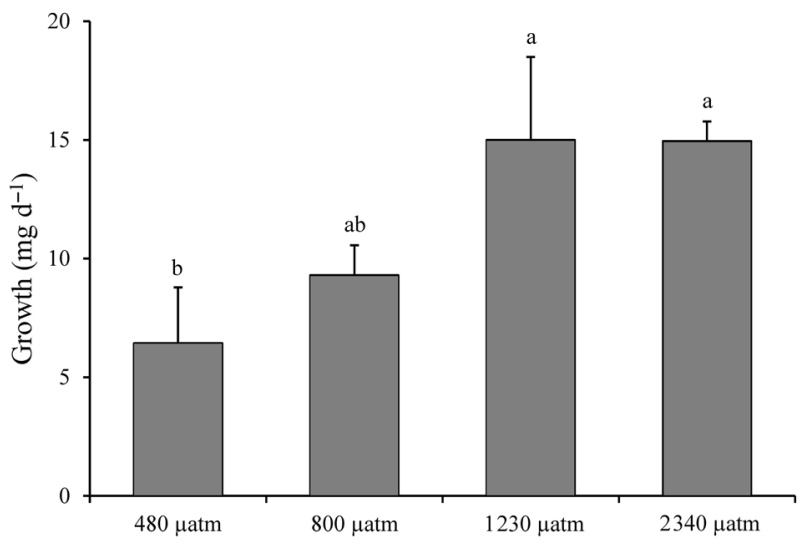

Fig. 2. Mean (SD) growth rates of Saccharina latissima grown under treatment $p \mathrm{CO}_{2}$ levels with nutrient additions (' $p \mathrm{CO}_{2}$ dose response'; Table 2). Statistical analyses: 2-way ANOVA and post hoc Tukey's HSD tests ( $\mathrm{n}=4$ for all treatments); significant differences $(p<0.05)$ between treatments indicated by letters

(1-way ANOVA and Tukey's HSD, p > 0.05; Fig. 2, Tables S3 \& S4). Further, there was no difference in growth between the 800, 1200, and $\sim 2300 \mu \mathrm{atm}$ $p \mathrm{CO}_{2}$ treatments (1-way ANOVA and Tukey's HSD, p > 0.05 for both; Fig. 2, Tables S3 \& S4).

\subsection{S. latissima tissue analyses}

During the 'co-effects of $p \mathrm{CO}_{2}$ and nutrients' experiment, tissue $\delta^{13} \mathrm{C}$ was significantly lower under elevated $p \mathrm{CO}_{2}(-29 \%)$ relative to ambient conditions $(-16 \%)$ (2-way ANOVA and Tukey's HSD, $\mathrm{p}<0.05$; Fig. 3, Tables S5 \& S6), while nutrients did not significantly alter $\delta^{13} \mathrm{C}$ (2-way ANOVA, $\mathrm{p}>0.05$; Fig. 3, Tables S5 \& S6). The mixing model performed for this experiment showed the actual $\delta^{13} \mathrm{C}$ signatures following exposure to elevated $p \mathrm{CO}_{2}(-27.9 \%)$ to be similar to predicted $\delta^{13} \mathrm{C}$ for exclusive uptake of $\mathrm{CO}_{2}$ $(-26.8 \%)$ as opposed to exclusive $\mathrm{HCO}_{3}{ }^{-}$uptake $(-16.3 \%)$. In the ' $p \mathrm{CO}_{2}$ dose response' experiment, the $\sim 2300 \mu \mathrm{atm} p \mathrm{CO}_{2}$ treatment had significantly lower tissue $\delta^{13} \mathrm{C}(-22 \%)$ than in the $\sim 500$ and $\sim 800 \mu \mathrm{atm} p \mathrm{CO}_{2}$ treatments ( -18 and $-19 \%$, respectively) (2-way ANOVA and Tukey's HSD, $\mathrm{p}<0.05$ for both; Fig. 3, Tables S5 \& S6). While tissue $\delta^{13} \mathrm{C}$ in the $\sim 1200 \mu$ atm $p \mathrm{CO}_{2}$ treatment $(-21 \%)$ was significantly lower than in the $\sim 500 \mu$ atm $p \mathrm{CO}_{2}$ treatment (2-way ANOVA and Tukey's HSD, p < 0.05; Fig. 3, Tables S5 \& S6), there was no significant difference in $\delta^{13} \mathrm{C}$ between the $\sim 1200$ and $\sim 800 \mu$ atm $p \mathrm{CO}_{2}$ treatments (2-way ANOVA and Tukey's HSD; p > 0.05 ; Fig. 3, Tables S5 \& S6). There was no significant 


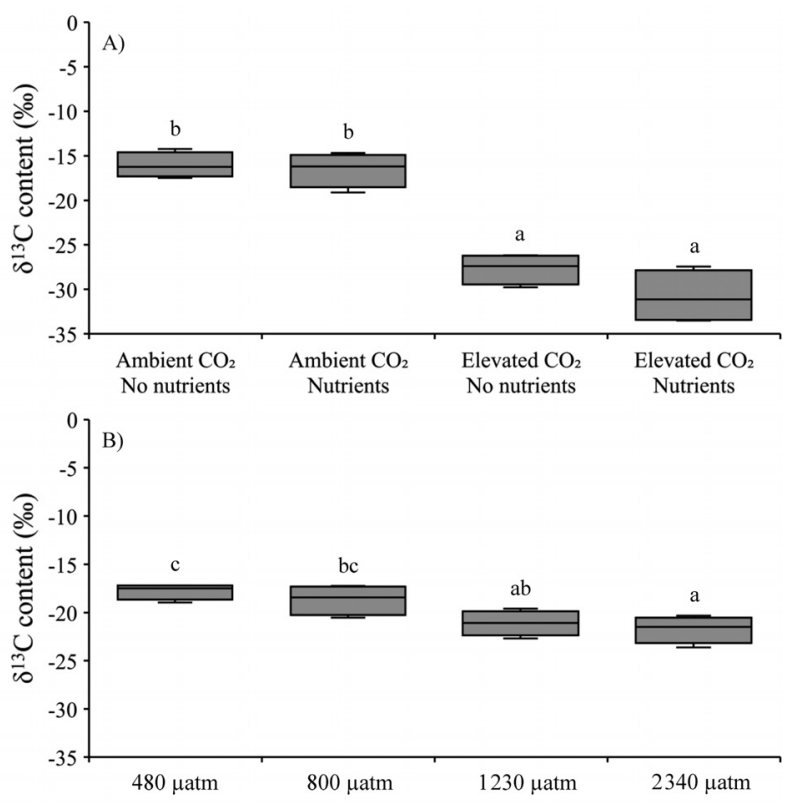

Fig. 3. Mean $( \pm \mathrm{SD})$ tissue $\delta^{13} \mathrm{C}$ content of Saccharina latissima grown under treatment $p \mathrm{CO}_{2}$ levels with nutrient additions for the (A) 'Co-effects of $p \mathrm{CO}_{2}$ and nutrients' and (B) ' $p \mathrm{CO}_{2}$ dose response' experiments, respectively (Table 2). Statistical analyses: 2-way ANOVA and post hoc Tukey's HSD tests ( $\mathrm{n}=4$ for all treatments); significant differences $(p<0.05)$ between treatments indicated by letters

difference in $\delta^{13} \mathrm{C}$ between the $\sim 500$ and $\sim 800 \mu \mathrm{atm}$ $p \mathrm{CO}_{2}$ treatments (2-way ANOVA and Tukey's HSD, p > 0.05; Fig. 3, Tables S5 \& S6). Mixing models performed for the $\sim 800, \sim 1200$, and $\sim 2300 \mu$ atm $p \mathrm{CO}_{2}$ treatments showed the actual $\delta^{13} \mathrm{C}$ signatures $(-18.7$, -21.6 , and $-22.2 \%$, respectively) of $S$. latissima shifted from being similar to predicted $\delta^{13} \mathrm{C}$ signatures from exclusive $\mathrm{HCO}_{3}{ }^{-}$use $(-15.8 \%$ for all) to predicted signatures from exclusive $\mathrm{CO}_{2}$ use $(-28.1,-27.6$, and $-25.2 \%$, respectively) as $p \mathrm{CO}_{2}$ levels increased across treatments. There were no significant differences in tissue $\mathrm{C}, \mathrm{N}$, and $\mathrm{C}: \mathrm{N}$ between any of the $p \mathrm{CO}_{2}$ treatments (2way ANOVA and Tukey's HSD, $\mathrm{p}>0.05$ for all; Table 3, Tables S7-S9).

\subsection{Herbivory rates of Lacuna vincta grazing on S. latissima}

During the 'effects of high and low $p \mathrm{CO}_{2}$ on herbivory' experiment, which examined how high and low $p \mathrm{CO}_{2}$ affected herbivory of Lacuna vincta that were fed S. latissima, grazing rates in the elevated $p \mathrm{CO}_{2}$ treatment were signifi- cantly reduced by $60 \%$ relative to the ambient $p \mathrm{CO}_{2}$ after $48 \mathrm{~h}$ (1-way ANOVA, $\mathrm{p}<0.05$; Fig. 4, Table S10). For the 'direct vs. indirect effects of elevated $p \mathrm{CO}_{2}$ on herbivory' experiment, $L$. vincta herbivory rates were sensitive to $p \mathrm{CO}_{2}$ levels during the starvation period, but not the $p \mathrm{CO}_{2}$ conditions that $S$. latissima were incubated under (Fig. 5). Specifically, for the 24, 48, and $72 \mathrm{~h}$ timepoints, herbivory was significantly decreased by $\sim 78, \sim 86$, and $\sim 94 \%$ when Lacuna were starved under elevated $p \mathrm{CO}_{2}$ relative to ambient conditions (2way ANOVA, p < 0.05 for all; Fig. 5, Table S11). In contrast, herbivory was not significantly altered by the $p \mathrm{CO}_{2}$ conditions in which $S$. latissima were grown under throughout the experiment (2-way ANOVA, p > 0.05 for all; Fig. 5, Table S11). After 96 h, herbivory rates of $L$. vincta exposed to elevated $p \mathrm{CO}_{2}$ recovered and were no longer affected by the $p \mathrm{CO}_{2}$ levels it had been exposed to during the starvation period (2-way ANOVA, $p>0.05$ for both; Fig. 5, Table S11).

In the 'co-effects of elevated $p \mathrm{CO}_{2}$ and food restriction on herbivory' experiment, $p \mathrm{CO}_{2}$ levels and being starved or fed prior to grazing was examined in a $2 \times 2$ experimental design. While herbivory rates of $L$. vincta on $S$. latissima during this experiment were not significantly affected by whether snails were starved under ambient $p \mathrm{CO}_{2}$ (2-way ANOVA, $\mathrm{p}>0.05$; Fig. 6 , Tables $\mathrm{S} 12$ \& S13), exposure to elevated $p \mathrm{CO}_{2}$ during the starvation period significantly depressed herbivory rates of starved snails (2-way ANOVA and Tukey's HSD, p < 0.05; Fig. 6, Tables S12 \& S13). Within the elevated $p \mathrm{CO}_{2}$ treatments, $L$. vincta that were starved had herbivory rates that were $~ 85 \%$ lower than individuals that were fed throughout experimentation (Tukey's HSD, $\mathrm{p}<0.05$; Fig. 6, Tables S12 \& S13).

During the 'effective minimum exposure duration' experiment, exposure to elevated $p \mathrm{CO}_{2}$ levels for 6

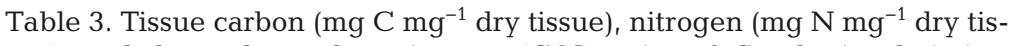
sue), and the molar carbon:nitrogen $(\mathrm{C}: \mathrm{N})$ ratios of Saccharina latissima grown under ambient or elevated $p \mathrm{CO}_{2}$ with and without nutrient additions ('Co-effects of $p \mathrm{CO}_{2}$ and nutrients') or under treatment $p \mathrm{CO}_{2}$ levels with nutrient additions (' $p \mathrm{CO}_{2}$ dose response'; Table 2)

\begin{tabular}{|clccc|}
\hline Experiment & Treatment & Tissue C & Tissue N & C:N \\
\hline $\begin{array}{c}\text { Co-effects of } \\
p \mathrm{CO}_{2} \text { and }\end{array}$ & Control & $0.32 \pm 0.01$ & $0.0104 \pm 0.0004$ & $30.5 \pm 2.4$ \\
nutrients & $\mathrm{CO}_{2}$ & $0.33 \pm 0.01$ & $0.0109 \pm 0.0007$ & $29.6 \pm 2.4$ \\
& $\mathrm{CO}_{2} /$ Nutrients & $0.33 \pm 0.02$ & $0.0095 \pm 0.0011$ & $35.2 \pm 4.8$ \\
$p \mathrm{CO}_{2}$ dose & Ambient $p \mathrm{CO}_{2}$ & $0.33 \pm 0.01$ & $0.0160 \pm 0.0032$ & $21.4 \pm 4.4$ \\
response & Low $p \mathrm{CO}_{2}$ & $0.33 \pm 0.02$ & $0.0160 \pm 0.0036$ & $21.6 \pm 6.7$ \\
& Medium $p \mathrm{CO}_{2}$ & $0.33 \pm 0.02$ & $0.0169 \pm 0.0022$ & $19.8 \pm 4.0$ \\
& High $p \mathrm{CO}_{2}$ & $0.34 \pm 0.01$ & $0.0148 \pm 0.0018$ & $22.9 \pm 3.3$ \\
\hline
\end{tabular}




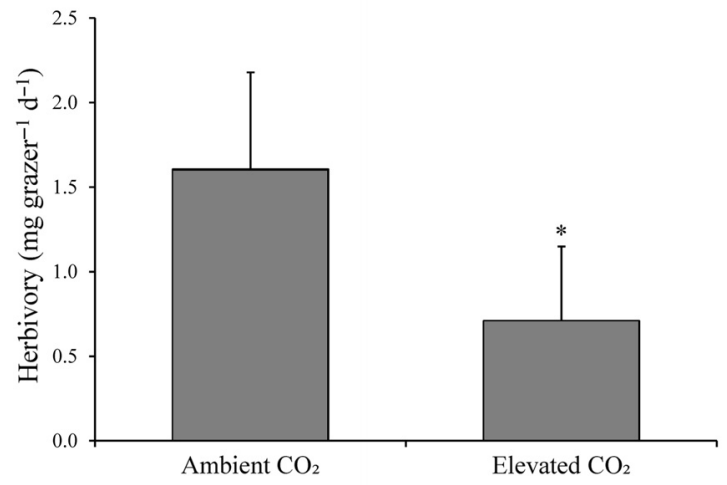

Fig. 4. Mean (SD) herbivory rates of Lacuna vincta starved and allowed to graze on Saccharina latissima under ambient and elevated $p \mathrm{CO}_{2}$ levels for $48 \mathrm{~h}$ ('Effects of high and low $p \mathrm{CO}_{2}$ on herbivory'; Table 2). Statistical analyses: 1-way ANOVA performed for the $48 \mathrm{~h}$ grazing period $(\mathrm{n}=4$ for all treatments) ${ }^{*} \mathrm{p}<0.05$

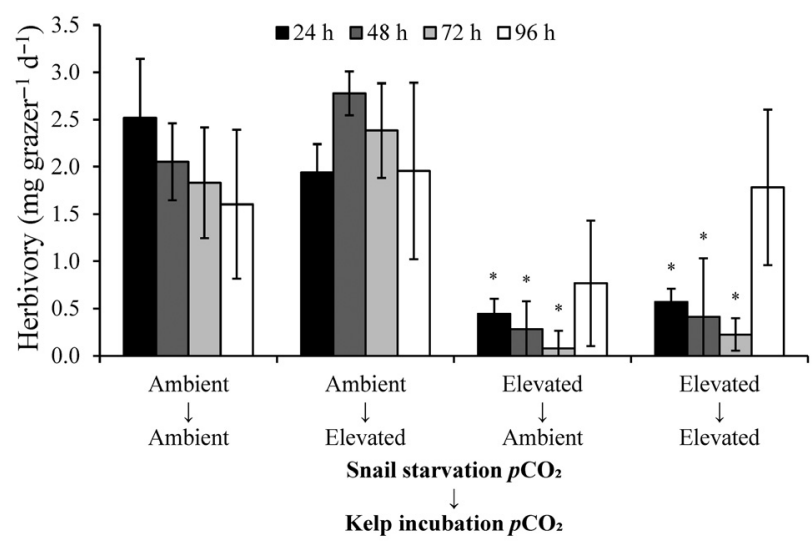

Fig. 5. Mean $( \pm \mathrm{SD})$ herbivory rates of Lacuna vincta grazing on Saccharina latissima under ambient or elevated $p \mathrm{CO}_{2}$ levels with $S$. latissima pre-incubated for 1 wk under ambient or elevated $p \mathrm{CO}_{2}$ ('Direct vs. indirect effects of elevated $p \mathrm{CO}_{2}$ on herbivory'; Table 2). Statistical analyses: 2-way ANOVA and post hoc Tukey's HSD tests performed for each $24 \mathrm{~h} \mathrm{graz-}$ ing period ( $\mathrm{n}=4$ for all treatments). ${ }^{*} \mathrm{p}<0.05$ between treatments for each $24 \mathrm{~h}$ grazing period relative to the control (ambient $p \mathrm{CO}_{2}$ snail starvation $\rightarrow$ ambient $p \mathrm{CO}_{2}$ kelp incubation)

or $12 \mathrm{~h}$ did not alter herbivory rates compared to the control (1-way ANOVA and Tukey's HSD, p > 0.05 for all; Fig. 7, Tables S14 \& S15) but 18 and $24 \mathrm{~h}$ exposure did, yielding rates significantly lower than the 0,6 , and $12 \mathrm{~h}$ exposure treatments (1-way ANOVA and Tukey's HSD, $\mathrm{p}<0.05$ for all; Fig. 7, Tables S14 $\&$ S15). There was no significant difference in herbivory between the 18 and $24 \mathrm{~h}$ exposure treatments (1-way ANOVA and Tukey's HSD, p < 0.05; Fig. 7, Tables S14 \& S15).

Finally, during the 'effective minimum dose' experiment, $p \mathrm{CO}_{2}$ concentrations reduced herbivory rates of $L$. vincta feeding on $S$. latissima in a dose-

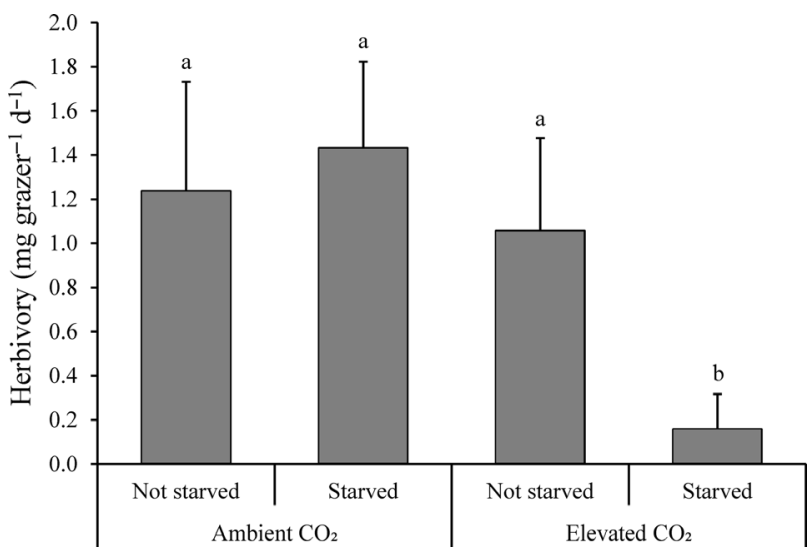

Fig. 6. Mean (SD) herbivory rates of Lacuna vincta either starved or not starved for $24 \mathrm{~h}$ under ambient or elevated $p \mathrm{CO}_{2}$ levels and allowed to graze on Saccharina latissima for $24 \mathrm{~h}$ ('Co-effects of elevated $p \mathrm{CO}_{2}$ and food restriction on herbivory'; Table 2). Statistical analyses: 2-way ANOVA and post hoc Tukey's HSD tests ( $\mathrm{n}=4$ for all treatments); significant differences $(p<0.05)$ between treatments indicated by letters

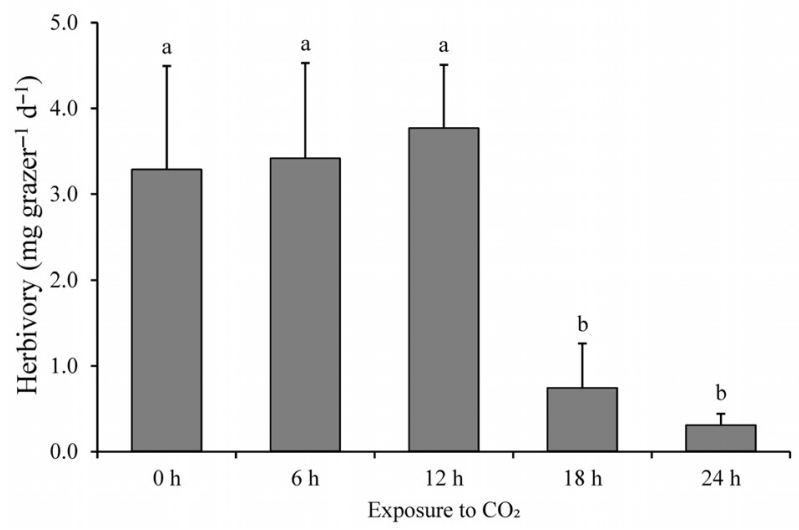

Fig. 7. Mean (SD) herbivory rates of Lacuna vincta starved for various lengths of time under ambient and elevated $p \mathrm{CO}_{2}$ levels and allowed to graze on Saccharina latissima under ambient $p \mathrm{CO}_{2}$ for $24 \mathrm{~h}$ ('Effective minimum exposure duration'; Table 2). Statistical analyses: 1-way ANOVA and post hoc Tukey's HSD tests ( $\mathrm{n}=4$ for all treatments); significant differences $(p<0.05)$ between treatments indicated by letters

dependent manner. Herbivory rates within the $\sim 830$, $\sim 1420$, and $\sim 2450 \mu \mathrm{atm} p \mathrm{CO}_{2}$ treatments were all significantly lower than in the ambient $(\sim 450 \mu \mathrm{atm})$ $p \mathrm{CO} 2$ treatment (1-way ANOVA and Tukey's HSD, $\mathrm{p}<0.05$ for all; Fig. 8, Tables S16 \& S17). While herbivory rates in the $\sim 830 \mu \mathrm{atm} p \mathrm{CO}_{2}$ treatment were significantly higher than in the $\sim 1420$ and $\sim 2450 \mu \mathrm{atm}$ $p \mathrm{CO}_{2}$ treatments (1-way ANOVA and Tukey's HSD, $\mathrm{p}<0.05$ for both; Fig. 8, Tables S16 \& S17), there was no significant difference in herbivory between the 1420 and $2450 \mu \mathrm{atm} p \mathrm{CO}_{2}$ treatments (1-way ANOVA and Tukey's HSD, $p>0.05$; Fig. 8, Tables $\mathrm{S} 16$ \& $\mathrm{S} 17)$. 


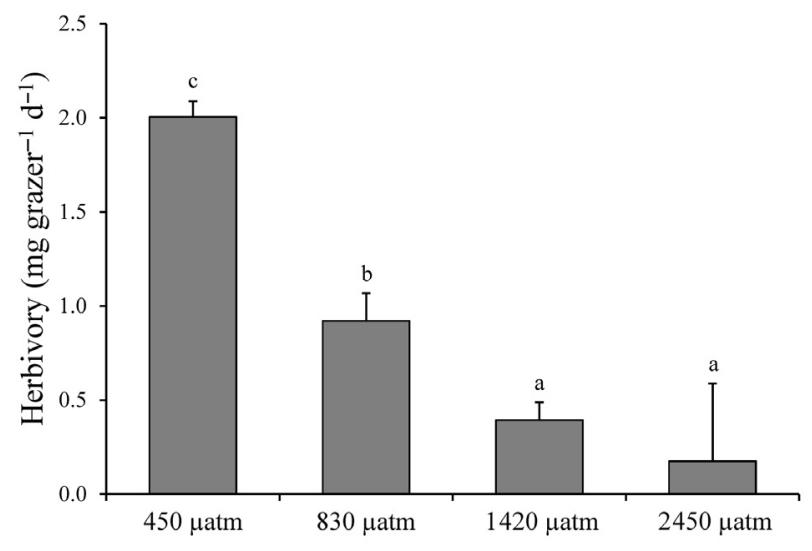

Fig. 8. Mean (SD) herbivory rates of Lacuna vincta starved for $24 \mathrm{~h}$ and allowed to graze on Saccharina latissima for $24 \mathrm{~h}$ under treatment $p \mathrm{CO}_{2}$ levels ('Effective minimum dose'; Table 2). Statistical analyses: 1-way ANOVA and post hoc Tukey's HSD ( $\mathrm{n}=4$ for all treatments); significant differences $(p<0.05)$ between treatments indicated by letters

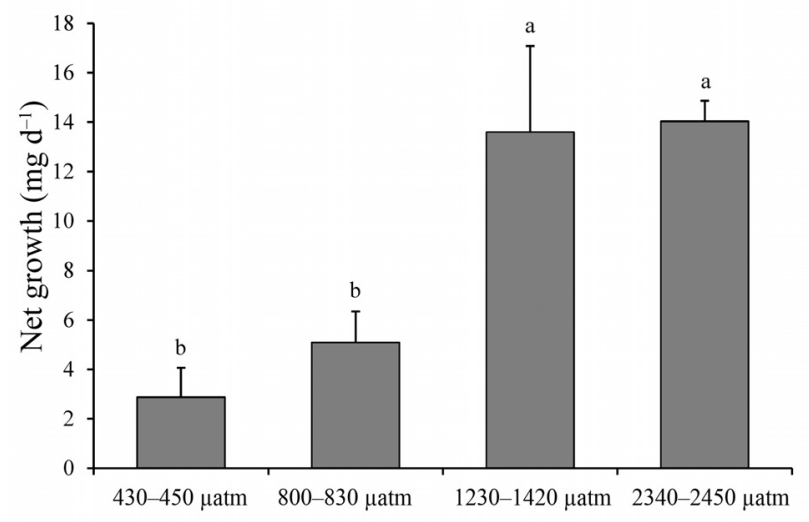

Fig. 9. Mean (SD) net growth rates of Saccharina latissima grown under treatment $p \mathrm{CO}_{2}$ levels following grazing by Lacuna vincta under the same $p \mathrm{CO}_{2}$ conditions. The net growth rates consider the growth rates of $S$. latissima and herbivory rates of $L$. vincta from the ' $p \mathrm{CO}_{2}$ dose response' and 'Effective minimum dose' experiments, respectively (Table 2). Statistical analyses: 1-way ANOVA and post hoc Tukey's HSD tests ( $\mathrm{n}=4$ for all treatments); significant differences $(p<0.05)$ between treatments indicated by letters

\subsection{Net growth rates}

Net growth rates of $S$. latissima (growth - grazing) were determined by considering growth under the range of $p \mathrm{CO}_{2}$ levels in the ' $p \mathrm{CO}_{2}$ dose response' experiment and herbivory rates of L. vincta grazing on $S$. latissima under approximately the same $p \mathrm{CO}_{2}$ conditions in the 'effective minimum dose' experiment. Net growth rates increased as $p \mathrm{CO}_{2}$ levels increased above $1200 \mu \mathrm{atm}$. At 1230-1420 and 23402450 atm $p \mathrm{CO}_{2}$ levels, net growth $\left(\sim 14 \mathrm{mg} \mathrm{d}^{-1}\right)$ was significantly higher than the ambient $\left(3 \mathrm{mg} \mathrm{d}^{-1}\right.$ at

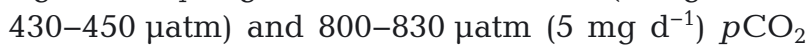
levels by more than 4 - and 2-fold, respectively (1way ANOVA and Tukey's HSD, p < 0.05 for all; Fig. 9, Tables S18 \& S19). There were no significant differences in net growth between the 430-450 and 800-830 $\mu \mathrm{atm} p \mathrm{CO}_{2}$ treatments or between the 1230-1420 and 2340-2450 $\mu$ atm $p \mathrm{CO}_{2}$ treatments (1-way ANOVA and Tukey's HSD, p > 0.05 for all; Fig. 9, Tables S18 \& S19).

\section{DISCUSSION}

Ocean acidification is restructuring the function of coastal ecosystems. Given the potential for elevated $p \mathrm{CO}_{2}$ to promote the growth of some autotrophs and to negatively affect some calcifying organisms, interactions between herbivorous calcifiers and macroalgae may be significantly altered by ocean acidification. During the present study, growth rates of the ecologically and economically important kelp species Saccharina latissima were enhanced by elevated $p \mathrm{CO}_{2}$ levels, while herbivory rates of Lacuna vincta grazing on $S$. latissima were reduced when exposed to elevated $p \mathrm{CO}_{2}$ and deprived of food prior to exposure. This study demonstrates, to our knowledge for the first time, the ability of ocean acidification to benefit the growth of a macrophyte by concurrently altering both top-down (herbivory) and bottom-up (growth) processes.

During this study, S. latissima growth was significantly increased under elevated $p \mathrm{CO}_{2}$, an outcome consistent with prior studies (Hepburn et al. 2011, Olischläger et al. 2012, Zhang et al. 2020). While these effects could have been temperature-dependent, our use of in situ temperatures from our study site did not allow for detection of such trends. The physiological response of macroalgae to elevated $p \mathrm{CO}_{2}$ levels is largely dependent on its mode of carbon uptake and the extent to which its inorganic carbon uptake is substrate-saturated at current $p \mathrm{CO}_{2}$ levels (Koch et al. 2013). When exposed to elevated $p \mathrm{CO}_{2}$ levels, macroalgae may be relived of $\mathrm{C}$ limitation and/or may downregulate carbon-concentrating mechanisms that convert $\mathrm{HCO}_{3}{ }^{-}$to $\mathrm{CO}_{2}$, allowing for more energy to be available for vegetative growth (Mercado et al. 1998, Koch et al. 2013). The tissue $\delta^{13} \mathrm{C}$ content of macroalgae can indicate the form of inorganic carbon used for photosynthesis, with values of $-10 \%$ indicative sole use of $\mathrm{HCO}_{3}{ }^{-}$, values of -10 to $-30 \%$ indicative use of both $\mathrm{HCO}_{3}{ }^{-}$and $\mathrm{CO}_{2}$, and values of $-30 \%$ or lower representing sole use of 
$\mathrm{CO}_{2}$ (Maberly et al. 1992, Raven et al. 2002, Hepburn et al. 2011). In the present study, S. latissima had $\delta^{13} \mathrm{C}$ signatures that ranged from -16 to $-18 \%$ when exposed to normal conditions, suggesting it primarily, but not exclusively, uses $\mathrm{HCO}_{3}^{-}$as a $\mathrm{C}$ source under ambient $p \mathrm{CO}_{2}$ conditions (Maberly et al. 1992, Raven et al. 2002, Hepburn et al. 2011). Exposure to elevated $p \mathrm{CO}_{2}$ significantly lowered $\delta^{13} \mathrm{C}$ signatures $(-18$ to $-29 \%$ o) of $S$. latissima, indicating that when exposed to higher $p \mathrm{CO}_{2}$ levels, this alga obtained a larger fraction of its $\mathrm{C}$ from $\mathrm{CO}_{2}$, an observation consistent with previous studies of stable carbon isotope discrimination of $S$. latissima and other laminarian kelp species (Maberly et al. 1992, Fernández et al. 2015). Furthermore, in the present study, growth rates increased under increasing $p \mathrm{CO}_{2}$ levels up to $\sim 1200 \mu \mathrm{atm}$, suggesting that $S$. latissima may become substrate-saturated at this concentration. While this level of $p \mathrm{CO}_{2}$ is not predicted to occur in open ocean regions for more than a century, it can occur regularly in some coastal systems (Feely et al. 2008, Melzner et al. 2013, Wallace et al. 2014). Be it in the future or due to present day coastal processes, elevated $p \mathrm{CO}_{2}$ levels may directly benefit the growth of laminarian kelp species such as $S$. latissima.

Nutrients also increased $S$. latissima growth rates, although there was no interaction with $p \mathrm{CO}_{2}$ levels. Eutrophication can initiate phase shifts in coastal ecosystems whereby turf algae benefit from the overloading of nutrients and cover substrate onto which kelp may grow and recruit, causing declines in kelp forests (Eriksson et al. 2002, Gorgula \& Connell 2004, Connell et al. 2008). However, kelps including $S$. latissima can grow robustly using aquaculture approaches in eutrophic ecosystems (Kim et al. 2015, Jiang et al. 2020), and the results shown here demonstrate that, without competition, elevated nutrients can benefit $S$. latissima via enhanced growth rates.

Beyond growth, herbivory on S. latissima also changed under elevated $p \mathrm{CO}_{2}$. The effects of elevated $p \mathrm{CO}_{2}$ and the absence of food on the herbivory rates of $L$. vincta are consistent with prior observations regarding the manner in which acidification alters herbivory by this gastropod grazing on the green alga, Ulva (Young et al. 2019). In the present study, herbivory by L. vincta on S. latissima was even more sensitive to acidification, with food limitation decreasing herbivory rates at $830 \mu \mathrm{atm}$, slightly lower than the level at which $L$. vincta grazing on Ulva was reduced (850 $\mu \mathrm{atm}$; Young et al. 2019). Exposure to elevated $p \mathrm{CO}_{2}$ levels may cause a state of acidosis that can disrupt metabolism and homeostatic function, thus diverting energy from critical functions such shell and somatic growth, shell repair, and gametogenesis (Lindinger et al. 1984, Pörtner et al. 1998, Hendriks et al. 2010). L. vincta exposed to elevated $p \mathrm{CO}_{2}$ and starved display lower respiration rates (Young et al. 2019), a finding interpreted as metabolic depression within other marine gastropods during periods of food limitation (Maas et al. 2011). The ability of acidification alone to slow the metabolism of gastropods has also been previously reported (Hendriks et al. 2010, Melatunan et al. 2011), which may serve as a survival strategy to match lowered energy supply (Bishop \& Brand 2000) and may result in an increased reliance on anaerobic respiration (Pörtner et al. 1998, Melatunan et al. 2011). Reductions in herbivory under elevated $p \mathrm{CO}_{2}$ were not observed when $L$. vincta was fed ad libitum, however. Similarly, when provided with an adequate food source, some other calcifying organisms (Melzner et al. 2011, Thomsen et al. 2013, Pansch et al. 2014) and early life stage fish (Gobler et al. 2018) are resistant to acidification.

In an ecosystem setting, kelp beds may provide a refuge to grazers by simultaneously buffering carbonate chemistry and providing ample quantities of food. Previous studies have demonstrated the ability of macroalgae to buffer carbonate chemistry and promote the growth and survival of calcifying organisms (Wahl et al. 2018, Young \& Gobler 2018). However, such a buffering effect can be species- and/or site-specific (Rivest et al. 2017). Daytime primary productivity within kelp beds has been shown to significantly reduce $p \mathrm{CO}_{2}$ compared to outside the bed on diel and even seasonal timescales (Delille et al. 2000, 2009). Furthermore, vertical gradients in $p \mathrm{CO}_{2}$ can also form in kelp canopies due to enhanced primary productivity in surface waters (Hofmann et al. 2011). The lower quantities of food and relatively higher levels of $p \mathrm{CO}_{2}$ on the vertical or horizontal margins of the kelp beds may be the regions more likely to facilitate disruption of gastropod herbivory. Similarly, acidified regions with low-density kelp blades could similarly be disruptive to snail grazing. All these conditions would be exacerbated by nocturnal acidification (Wallace et al. 2014, Tomasetti \& Gobler 2020).

While the $p \mathrm{CO}_{2}$ levels in the present study are not expected for the open ocean for decades or centuries to come, eutrophication, upwelling, riverine discharge, and other coastal processes may result in the diurnal and/or seasonal accumulation of $\mathrm{CO}_{2}$ in coastal zones that can produce the $p \mathrm{CO}_{2}$ and nutrient levels shown here to accelerate the growth of, and reduce grazing on, S. latissima (Feely et al. 2008, 
Melzner et al. 2013, Wallace et al. 2014). In the present study, $18 \mathrm{~h}$ of exposure to elevated $p \mathrm{CO}_{2}$ in the absence of food suppressed $L$. vincta herbivory, with this effect persisting for $72 \mathrm{~h}$. In an ecosystem context, $L$. vincta and other gastropods and grazers sensitive to elevated $p \mathrm{CO}_{2}$ may be vulnerable to diurnal and seasonal shifts in $\mathrm{pH}$ and $p \mathrm{CO}_{2}$. During nighttime and/or low tides, eutrophic estuaries can become strongly net heterotrophic and produce acidified conditions that can persist $>18 \mathrm{~h}$ (Wallace et al. 2014, Baumann et al. 2015). These conditions are mostly likely to occur in temperate estuaries during the late summer, when microbial respiration rates accelerate acidification, and may persist into the fall (Wallace et al. 2014), which is the beginning of the growing season for numerous kelp species (Kim et al. 2015, Augyte et al. 2017). Aside from the diurnal and seasonal shifts in $p \mathrm{CO}_{2}$, acidified conditions often cooccur with low oxygen conditions in estuaries (Tomasetti \& Gobler 2020), and the combination of hypoxia and acidification has been shown to additively and synergistically disrupt grazing by $L$ vincta (Young \& Gobler 2020). Finally, the elevated nutrients associated with eutrophication may also affect herbivory rates by $L$. vincta and growth by $S$. latissima. Nutrient enrichment can reduce the abundance of common estuarine grazers, including Lacuna, due to potentially toxic concentrations of ammonia (Atalah \& Crowe 2012). While eutrophication indirectly harms $S$. latissima via reduced light availability and overgrowth by epiphytic and filamentous algae (Moy \& Christie 2012), the alga can directly benefit from the increased nutrient concentrations (Boderskov et al. 2016, this study) and the acidification wrought from eutrophication (this study).

Despite the potential benefits that ocean acidification may provide to some primary producers (Koch et al. 2013, Hattenrath-Lehmann et al. 2015, Young \& Gobler 2016), grazing pressure by common herbivores, such as gastropods, may limit the extent of these benefits through top-down controls on growth (Baggini et al. 2015). Among the factors that limit kelp abundance, overgrazing is a major biotic driver of kelp loss via consumption of kelp blades, inhibition of new recruitment, and/or grazing damage causing blade breakage (Steneck et al. 2002, Molis et al. 2010, Filbee-Dexter \& Wernberg 2018). As L. vincta is the primary mesograzer of $S$. latissima macroscopic kelp sporophytes in the Northwest Atlantic (Brady-Campbell et al. 1984, Johnson \& Mann 1986), large population increases in the gastropod can consume significant quantities of kelp biomass, which can result in significant losses of kelp canopy biomass due to wave action (Krumhansl \& Scheibling 2011). Studies have shown that $L$. vincta grazing of kelp can remove up to $10 \%$ of the total surface area of blades in natural settings (Molis et al. 2010, Krumhansl \& Scheibling 2011) and larger amounts (>40\%) in experimental settings (Chenelot \& Konar 2007). In the present study, $L$. vincta displayed significantly reduced herbivory when exposed to elevated $p \mathrm{CO}_{2}$ and prior food restriction, while $S$. latissima growth was significantly increased under elevated $p \mathrm{CO}_{2}$. When considering the responses of $S$. latissima across a $p \mathrm{CO}_{2}$ gradient, net growth rates increased more than 4 -fold from under ambient $p \mathrm{CO}_{2}$ to $\sim 1200 \mu \mathrm{uatm}$ (Fig. 9). L. vincta had the potential to consume $70 \% S$. latissima productivity per day under ambient $p \mathrm{CO}_{2}$, but only 38 and $9 \%$ at 800 and $1300 \mu \mathrm{atm}$, respectively, meaning that as $p \mathrm{CO}_{2}$ levels rise, $L$. vincta, and other gastropods that experience reduced herbivory rates under elevated $p \mathrm{CO}_{2}$, may become incapable of controlling kelp proliferation.

Beyond growth and grazing, competition with other algae will also influence the fate of S. latissima populations in high- $\mathrm{CO}_{2}$ environments (Young \& Gobler 2017). During the last decade, turf-forming algae have begun to replace kelp beds in many ecosystems, primarily due to warming and eutrophication (Moy \& Christie 2012, Filbee-Dexter \& Wernberg 2018). In regions with naturally occurring high $\mathrm{CO}_{2}$ conditions from volcanic vents, however, turf algal communities decline in diversity and abundance with decreasing $\mathrm{pH}$ and increasing $p \mathrm{CO}_{2}$ (Porzio et al. 2011). Hence, beyond the ability of high $p \mathrm{CO}_{2}$ to foster higher net growth rates in S. latissima, these conditions may also allow it to maintain dominance in regions where it may be competing with turf-forming algae, possibly off-setting losses associated with other anthropogenic processes.

Within the northwestern Atlantic, L. vincta can reproduce year-round on kelp in cooler climates (Maney \& Ebersole 1990), with a distinctive peak in spawning during January and February (Johnson \& Mann 1986), larval recruitment and hatching occurring thereafter, followed by a summer maxima (Southgate 1982). Within the same regions, kelp species such as $S$. latissima begin their growing season during the fall, grow rapidly in spring, and experience rapid decay and mortality during the summer as thermal thresholds are surpassed (Krumhansl \& Scheibling 2011, Kim et al. 2015, Augyte et al. 2017). The emergence of marine gastropod grazers with the onset of the warmer summer weather accelerates the seasonal demise of kelp (Johnson \& Mann 1986, Krumhansl \& Scheibling 2011). As coastal waters sea- 
sonally warm, accelerating rates of ecosystem metabolism can cause a supersaturation of $p \mathrm{CO}_{2}$ (Wallace et al. 2014, Baumann et al. 2015) that may enhance the net growth rates of $S$. latissima and prolong the growing season of the kelp that might otherwise slow due to warmer temperatures and grazing (Wernberg et al. 2010, Filbee-Dexter et al. 2016). In the future, as climate change intensifies acidification, shortened growing seasons due to warming may be offset by increased net growth due to higher $p \mathrm{CO}_{2}$. Future experiments should consider the interactive effects of temperature and $p \mathrm{CO}_{2}$ on the growth of $S$. latissima.

\section{CONCLUSIONS}

Elevated levels of $p \mathrm{CO}_{2}$ have a dual benefit for the kelp Saccharina latissima. The net growth rates of $S$. latissima at higher $p \mathrm{CO}_{2}(>1200 \mu \mathrm{atm})$ exceeded those at ambient $p \mathrm{CO}_{2}$ by 4 -fold due to both accelerated growth by $S$. latissima and suppressed herbivory by the gastropod Lacuna vincta. The $p \mathrm{CO}_{2}$ conditions that elicited reduced herbivory $(\sim 830 \mu \mathrm{atm})$ and enhanced kelp growth $\left(\sim 1200 \mu\right.$ atm $\left.p \mathrm{CO}_{2}\right)$ are seasonally found in many estuaries today and will become more common in the future as climate change accelerates. Eutrophication associated with coastal acidification may benefit $S$. latissima directly through nutrient- and $\mathrm{CO}_{2}$-enhanced growth rates and may further reduce herbivore grazing due to hypoxia and/or high ammonia levels. Since only $18 \mathrm{~h}$ of acidification suppressed herbivory by L. vincta, nocturnal acidification associated with eutrophication (Wallace et al. 2014) may further suppress herbivore grazing. While $S$. latissima may buffer carbonate chemistry to the benefit of calcifying organisms such as $L$. vincta, these benefits may only be realized in the center of dense kelp beds as opposed to horizontal and vertical margins where acidification and gastropod starvation may become more common. Lastly, given that turf-forming algae may not directly benefit from increased $p \mathrm{CO}_{2}$, the combination of increased growth and suppressed herbivory experienced by $S$. latissima may allow the alga to maintain dominance facilitated by high- $\mathrm{CO}_{2}$ conditions.

Acknowledgements. We thank Brooke Morrell and Marissa Velasquez for their efforts in growing and collecting the Saccharina latissima used in the present study, and Andrew Lundstrom for assistance with the analysis of samples for DIC. We thank Paul McCormick at the Great Gun Shellfish Farm in Moriches Bay for use of his farm and assistance in cultivating kelp used in these experiments. We are appreciative of the logistic support provided by the Stony Brook
Southampton Marine Science Center staff throughout this study. This work was supported by funding from The Chicago Community Trust, the New York Farm Viability Institute, and New York Sea Grant (R-FBM-38).

\section{LITERATURE CITED}

Atalah J, Crowe TP (2012) Nutrient enrichment and variation in community structure on rocky shores: the potential of molluscan assemblages for biomonitoring. Estuar Coast Shelf Sci 99:162-170

Augyte S, Yarish C, Redmond S, Kim JK (2017) Cultivation of a morphologically distinct strain of the sugar kelp, Saccharina latissima forma angustissima, from coastal Maine, USA, with implications for ecosystems services. J Appl Phycol 29:1967-1976

Baggini C, Issaris Y, Salomidi M, Hall-Spencer J (2015) Herbivore diversity improves benthic community resilience to ocean acidification. J Exp Mar Biol Ecol 469:98-104

* Baumann H, Wallace RB, Tagliaferri T, Gobler CJ (2015) Large natural $\mathrm{pH}, \mathrm{CO}_{2}$ and $\mathrm{O}_{2}$ fluctuations in a temperate tidal salt marsh on diel, seasonal, and interannual time scales. Estuaries Coasts 38:220-231

*Bishop T, Brand MD (2000) Processes contributing to metabolic depression in hepatopancreas cells from the snail Helix aspersa. J Exp Biol 203:3603-3612

* Boderskov T, Schmedes PS, Bruhn A, Rasmussen MB, Nielsen MM, Pedersen MF (2016) The effect of light and nutrient availability on growth, nitrogen, and pigment contents of Saccharina latissima (Phaeophyceae) grown in outdoor tanks, under natural variation of sunlight and temperature, during autumn and early winter in Denmark. J Appl Phycol 28:1153-1165

* Brady-Campbell MM, Campbell DB, Harlin MM (1984) Productivity of kelp (Laminaria spp.) near the southern limit in the Northwestern Atlantic Ocean. Mar Ecol Prog Ser 18:79-88

*Binkhuis BH, Breda VA, Tobin S, Macler BA (1983) New York marine biomass program-culture of Laminaria saccharina. J World Maric Soc 14:360-379

Chavanich S, Harris LG (2002) The influence of macroalgae on seasonal abundance and feeding preference of a subtidal snail, Lacuna vincta (Montagu) (Littorinidae) in the Gulf of Maine. J Molluscan Stud 68:73-78

* Chenelot H, Konar B (2007) Lacuna vincta (Mollusca, Neotaenioglossa) herbivory on juvenile and adult Nereocystis luetkeana (Heterokontophyta, Laminariales). Hydrobiologia 583:107-118

兴Chung IK, Oak JH, Lee JA, Shin JA, Kim JG, Park KS (2013) Installing kelp forests/seaweed beds for mitigation and adaptation against global warming: Korean project overview. ICES J Mar Sci 70:1038-1044

Connell SD, Russell BD (2010) The direct effects of increasing $\mathrm{CO}_{2}$ and temperature on non-calcifying organisms: increasing the potential for phase shifts in kelp forests. Proc R Soc B 277:1409-1415

Connell SD, Russell BD, Turner DJ, Shepherd SA and others (2008) Recovering a lost baseline: missing kelp forests from a metropolitan coast. Mar Ecol Prog Ser 360:63-72

* Delille B, Delille D, Fiala M, Prevost C, Frankignoulle M (2000) Seasonal changes of $p \mathrm{CO}_{2}$ over a subantarctic Macrocystis kelp bed. Polar Biol 23:706-716

*Delille B, Borges AV, Delille D (2009) Influence of giant kelp beds (Macrocystis pyrifera) on diel cycles of $\mathrm{pCO}_{2}$ and 
DIC in the sub-Antarctic coastal area. Estuar Coast Shelf Sci 81:114-122

*Doney SC, Fabry VJ, Feely RA, Kleypas JA (2009) Ocean acidification: the other $\mathrm{CO}_{2}$ problem. Annu Rev Mar Sci 1:169-192

Dubois A, Iken K (2012) Seasonal variation in kelp phlorotannins in relation to grazer abundance and environmental variables in the Alaskan sublittoral zone. Algae 27:9-19

Duffy E, Stachowicz J, Hovel K, Reynolds P (2014) Zostera experimental network handbook, v1. Smithsonian Environmental Research Center, Edgewater, MD

* Eriksson BK, Johansson G, Snoeijs P (2002) Long-term changes in the macroalgal vegetation of the inner Gullmar Fjord, Swedish Skagerrak coast. J Phycol 38:284-296

Feely RA, Sabine CL, Hernandez-Ayon JM, Ianson D, Hales B (2008) Evidence for upwelling of corrosive 'acidified' water onto the continental shelf. Science 320:1490-1492

Feely RA, Doney SC, Cooley SR (2009) Ocean acidification: present conditions and future changes in a high- $\mathrm{CO}_{2}$ world. Oceanography (Wash DC) 22:36-47

Fernández PA, Roleda MY, Hurd CL (2015) Effects of ocean acidification on the photosynthetic performance, carbonic anhydrase activity and growth of the giant kelp Macrocystis pyrifera. Photosynth Res 124:293-304

Filbee-Dexter K, Wernberg T (2018) Rise of turfs: a new battlefront for globally declining kelp forests. Bioscience 68: 64-76

Filbee-Dexter K, Feehan CJ, Scheibling RE (2016) Largescale degradation of a kelp ecosystem in an ocean warming hotspot. Mar Ecol Prog Ser 543:141-152

* Gobler CJ, Buck NJ, Sieracki ME, Sañudo-Wilhelmy SA (2006) Nitrogen and silicon limitation of phytoplankton communities across an urban estuary: the East RiverLong Island Sound system. Estuar Coast Shelf Sci 68: 127-138

* Gobler CJ, Berry DL, Dyhrman ST, Wilhelm SW and others (2011) Niche of harmful alga Aureococcus anophagefferens revealed through ecogenomics. Proc Natl Acad Sci USA 108:4352-4357

* Gobler CJ, Merlo LR, Morell BK, Griffith AW (2018) Temperature, acidification, and food supply interact to negatively affect the growth and survival of the forage fish, Menidia beryllina (inland silverside) and Cyprinodon variegatus (sheepshed minnow). Front Mar Sci 5:86

* Gorgula SK, Connell SD (2004) Expansive covers of turfforming algae on human-dominated coast: the relative effects of increasing nutrient and sediment loads. Mar Biol 145:613-619

*Hattenrath-Lehmann TK, Smith JL, Wallace RB, Merlo LR and others (2015) The effects of elevated $\mathrm{CO}_{2}$ on the growth and toxicity of field populations and cultures of the saxitoxin-producing dinoflagellate, Alexandrium fundyense. Limnol Oceanogr 60:198-214

* Hendriks IE, Duarte CM, Álvarez M (2010) Vulnerability of marine biodiversity to ocean acidification: a metaanalysis. Estuar Coast Shelf Sci 86:157-164

Hepburn CD, Pritchard DW, Cornwall CE, McLeod RJ, Beardall J, Raven JA (2011) Diversity of carbon use strategies in a kelp forest community: implications for a high $\mathrm{CO}_{2}$ ocean. Glob Change Biol 17:2488-2497

*Hofmann GE, Smith JE, Johnson KS, Send U and others (2011) High-frequency dynamics of ocean pH: a multiecosystem comparison. PLOS ONE 6:e28983

IPCC (2014) Climate change 2014: synthesis report. Contri- bution of Working Groups I, II, and III to the Fifth Assessment Report of the Intergovernmental Panel on Climate Change. IPCC, Geneva

Janiak DS, Whitlatch RB (2012) Epifaunal and algal assemblages associated with the native Chondrus crispus (Stackhouse) and the non-native Grateloupia turuturu (Yamada) in eastern Long Island Sound. J Exp Mar Biol Ecol 413:38-44

Jiang Z, Liu J, Li S, Chen Y and others (2020) Kelp cultivation effectively improves water quality and regulates phytoplankton community in a turbid, highly eutrophic bay. Sci Total Environ 707:135561

Johnson CR, Mann KH (1986) The importance of plant defence abilities to the structure of subtidal seaweed communities: the kelp Lamanaria longicruris de la Pylaie survives grazing by the snail Lacuna vincta (Montagu) at high population densities. J Exp Mar Biol Ecol 97:231-267

* Johnson KM, Wills KD, Butler DB, Johnson WK, Wong CS (1993) Coulometric total carbon dioxide analysis for marine studies: maximizing the performance of an automated gas extraction system and coulometric detector. Mar Chem 44:167-187

Kim JK, Kraemer GP, Yarish C (2015) Use of sugar kelp aquaculture in Long Island Sound and the Bronx River Estuary for nutrient extraction. Mar Ecol Prog Ser 531: 155-166

* Koch M, Bowes G, Ross C, Zhang XH (2013) Climate change and ocean acidification effects on seagrasses and marine macroalgae. Glob Change Biol 19:103-132

Krumhansl KA, Scheibling RE (2011) Spatial and temporal variation in grazing damage by the gastropod Lacuna vincta in Nova Scotian kelp beds. Aquat Biol 13:163-173

Lindinger MI, Lauren DJ, McDonald DG (1984) Acid-base balance in the sea mussel, Mytilus edulis. III. Effects of environmental hypercapnia on intra- and extracellular acid-base balance. Mar Biol Lett 5:371-381

Maas AE, Elder LE, Dierssen HM, Seibel BA (2011) Metabolic response of Antarctic pteropods (Mollusca: Gastropoda) to food deprivation and regional productivity. Mar Ecol Prog Ser 441:129-139

* Maberly SC, Raven JA, Johnston AM (1992) Discrimination between ${ }^{12} \mathrm{C}$ and ${ }^{13} \mathrm{C}$ by marine plants. Oecologia 91 : 481-492

Maney EJ, Ebersole JP (1990) Continuous reproduction and episodic recruitment of Lacuna vincta (Montagu, 1803) in the Gulf of Maine. Veliger 33:215-221

Marinho G, Holdt SL, Birkeland MJ, Angelidaki I (2015) Commercial cultivation and bioremediation potential of sugar kelp, Saccharina latissima, in Danish waters. J Appl Phycol 27:1963-1973

*Melatunan S, Calosi P, Rundle SD, Moody AJ, Widdicombe S (2011) Exposure to elevated temperature and $p \mathrm{CO}_{2}$ reduces respiration rate and energy status in the periwinkle Littorina littorea. Physiol Biochem Zool 84:583-594

* Melzner F, Stange P, Trübenbach K, Thomsen J and others (2011) Food supply and seawater $p \mathrm{CO}_{2}$ impact calcification and internal shell dissolution in the blue mussel Mytilus edulis. PLOS ONE 6:e24223

Melzner F, Jörn T, Koeve W, Oschlies A and others (2013) Future ocean acidification will be amplified by hypoxia in coastal habitats. Mar Biol 160:1875-1888

Mercado JM, Gordillo FJL, Niella FX, Figueroa FL (1998) External carbonic anhydrase and affinity for inorganic carbon in intertidal macroalgae. J Exp Mar Biol Ecol 221: 209-220 
Millero FJ (2010) History of the equation of state of seawater. Oceanography (Wash DC) 23:18-33

Molis M, Enge A, Karsten U (2010) Grazing impact of, and indirect interactions between mesograzers associated with kelp (Laminaria digitata). J Phycol 46:76-84

Moy FE, Christie H (2012) Large-scale shift from sugar kelp (Saccharina latissima) to ephemeral algae along the south and west coast of Norway. Mar Biol Res 8:309-321

Nelson TA, Haberlin K, Nelson AV, Ribarich H and others (2008) Ecological and physiological controls of species composition in green macroalgal blooms. Ecology 89: $1287-1298$

Norderhaug KM, Christie HC (2009) Sea urchin grazing and kelp re-vegetation in the NE Atlantic. Mar Biol Res 5: 515-528

*Norderhaug KM, Christie H, Fosså JH, Fredriksen S (2005) Fish-macrofauna interactions in a kelp (Laminaria hyperborea) forest. J Mar Biol Assoc UK 85:1279-1286

O'Brien JM, Scheibling RE (2016) Nipped in the bud: mesograzer feeding preference contributes to kelp decline. Ecology 97:1873-1886

* Olischläger M, Bartsch I, Gutow L, Wiencke C (2012) Effects of ocean acidification on different life-cycle stages of the kelp Laminaria hyperborea (Phaeophyceae). Bot Mar 55: 511-525

Pansch C, Schaub I, Havenhand J, Wahl M (2014) Habitat traits and food availability determine the response of marine invertebrates to ocean acidification. Glob Change Biol 20:765-777

Poloczanska ES, Burrows MT, Brown CJ, Molinos JG and others (2016) Responses of marine organisms to climate change across oceans. Front Mar Sci 3:62

* Pörtner HO, Reipschläger A, Heisler N (1998) Acid-base regulation, metabolism and energetics in Sipunculus nudus as a function of ambient carbon dioxide level. J Exp Biol 201:43-55

Porzio L, Buia MC, Hall-Spencer JM (2011) Effects of ocean acidification on macroalgal communities. J Exp Mar Biol Ecol 400:278-287

R Core Team (2020) R: a language and environment for statistical computing. R Foundation for Statistical Computing, Vienna. www.R-project.org

Raven JA, Johnston AM, Kübler JE, Korb R and others (2002) Mechanistic interpretation of carbon isotope discrimination by marine macroalgae and seagrasses. Funct Plant Biol 29:355-378

Raven JA, Gobler CJ, Hansen PJ (2020) Dynamic $\mathrm{CO}_{2}$ and $\mathrm{pH}$ levels in coastal, estuarine, and inland waters: theoretical and observed effects on harmful algal blooms. Harmful Algae 91:101594

Rivest EB, Comeau S, Cornwall CE (2017) The role of natural variability in shaping the response of coral reef organisms to climate change. Curr Clim Change Rep 3:271-281

RStudio Team (2020) RStudio: integrated development for R. RStudio, PBC, Boston, MA. http://rstudio.com/

Scheibling RE, Hennigar AW, Balch T (1999) Destructive grazing, epiphytism, and disease: the dynamics of sea urchin-kelp interactions in Nova Scotia. Can J Fish Aquat Sci 56:2300-2314

* Sivertsen K, Bjørge A (2015) On the brink of the Arctic: unusual intertidal sub-Arctic kelp associations in the Porsangerfjord, North Norway. Mar Biol Res 11:405-413

Smale DA, Burrows MT, Moore P, O'Connor N, Hawkins SJ (2013) Threats and knowledge gaps for ecosystem services provided by kelp forests: a northeast Atlantic per- spective. Ecol Evol 3:4016-4038

* Southgate T (1982) A comparative study of Lacuna vincta and Lacuna pallidula (Gastropoda: Prosobranchia) in littoral algal turfs. J Molluscan Stud 48:302-309

* Steneck RS, Graham MH, Bourque BJ, Corbett D, Erlandson JM, Estes JA, Tegner MJ (2002) Kelp forest ecosystems: biodiversity, stability, resilience and future. Environ Conserv 29:436-459

* Sunda WG, Cai WJ (2012) Eutrophication induced $\mathrm{CO}_{2}$ acidification of subsurface coastal waters: interactive effects of temperature, salinity, and atmospheric $p \mathrm{CO}_{2}$. Environ Sci Technol 46:10651-10659

Talmage SC, Gobler CJ (2010) Effects of past, present, and future ocean carbon dioxide concentrations on the growth and survival of larval shellfish. Proc Natl Acad Sci USA 107:17246-17251

* Thomsen J, Casties I, Pansch C, Körtzinger A, Melzner F (2013) Food availability outweighs ocean acidification effects in juvenile Mytilus edulis: laboratory and field experiments. Glob Change Biol 19:1017-1027

*Tomasetti SJ, Gobler CJ (2020) Dissolved oxygen and pH criteria leave fisheries at risk. Science 368:372-373

* Vargas CA, Contreras PY, Pérez CA, Sobarzo M, Saldías GS, Salisbury J (2016) Influences of riverine and upwelling waters on the coastal carbonate system off Central Chile and their ocean acidification implications. J Geophys Res Biogeosci 121:1468-1483

*Wahl M, Schneider Covachã S, Saderne V, Hiebenthal C, Müller JD, Pansch C, Sawall Y (2018) Macroalgae may mitigate ocean acidification effects on mussel calcification by increasing $\mathrm{pH}$ and its fluctuations. Limnol Oceanogr 63:3-21

*Wakefield RL, Murray SN (1998) Factors influencing food choice by the seaweed-eating marine snail Norrisia norrisi (Trochidae). Mar Biol 130:631-642

*Wallace RB, Baumann H, Grear JS, Aller RC, Gobler CJ (2014) Coastal ocean acidification: the other eutrophication problem. Estuar Coast Shelf Sci 148:1-13

*Wernberg T, Thomsen MS, Tuya F, Kendrick GA, Staehr PA, Toohey BD (2010) Decreasing resilience of kelp beds along a latitudinal temperature gradient: potential implications for a warmer future. Ecol Lett 13: 685-694

*Young CS, Gobler CJ (2016) Ocean acidification accelerates the growth of two bloom-forming macroalgae. PLOS ONE 11:e0155152

* Young CS, Gobler CJ (2017) The organizing effects of elevated $\mathrm{CO}_{2}$ on competition among estuarine primary producers. Sci Rep 7:7667

* Young CS, Gobler CJ (2018) The ability of macroalgae to mitigate the negative effects of ocean acidification on four species of North Atlantic bivalve. Biogeosciences 15: 6167-6183

* Young CS, Gobler CJ (2020) Hypoxia and acidification, individually and in combination, disrupt herbivory and reduce survivorship of the gastropod, Lacuna vincta. Front Mar Sci 7:547276

* Young CS, Lowell A, Peterson BJ, Gobler CJ (2019) Ocean acidification and food limitation combine to suppress herbivory by the gastropod Lacuna vincta. Mar Ecol Prog Ser 627:83-94

Z Zhang X, Xu D, Guan Z, Wang S and others (2020) Elevated $\mathrm{CO}_{2}$ concentrations promote growth and photosynthesis of the brown alga Saccharina japonica. J Appl Phycol 32: 1949-1959 